Aline Magalhães dos Santos

\title{
Atividade fotodinâmica dos fotossensibilizadores clorina e6 e azul de metileno associados a nanopartículas de ouro sintetizadas por ablação a laser
}

Dissertação de Mestrado

Dissertação apresentada como requisito parcial para obtenção do grau de Mestre pelo Programa de PósGraduação em Física da PUC-Rio.

Orientadora: Prof. a Sônia Renaux Wanderley Louro 


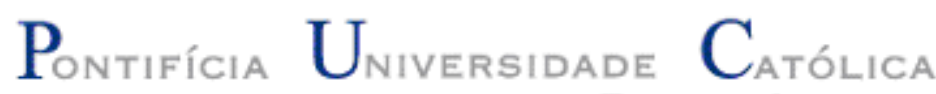

\section{Aline Magalhães dos Santos}

\section{Atividade fotodinâmica dos fotossensibilizadores clorina 66 e azul de metileno associados a nanopartículas de ouro sintetizadas por ablação a laser}

Dissertação apresentada como requisito parcial para obtenção do grau de Mestre pelo Programa de Pós-Graduação em Física do Departamento de Física do Centro Técnico Científico da PUC-Rio. Aprovada pela Comissão Examinadora abaixo assinada.

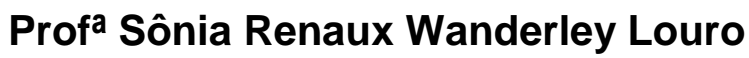

Orientadora Departamento de Física - PUC-Rio

Profa. Ana Maria Percebom Departamento de Química - PUC-Rio

Prof ${ }^{2}$. Ana Rosa Lopes Pereira Ribeiro Universidade do Grande Rio

Prof. Tommaso Del Rosso Departamento de Física - PUC-Rio

Prof. Márcio da Silveira Carvalho Coordenador Setorial do Centro Técnico Científico - PUC-Rio 
Todos os direitos reservados. É proibida a reprodução total ou parcial do trabalho sem autorização da universidade, do autor e do orientador.

\section{Aline Magalhães dos Santos}

Graduou-se em Física na Universidade Federal do Rio de Janeiro - UFRJ em 2015.

Ficha Catalográfica

Santos, Aline Magalhães dos

Atividade fotodinâmica dos fotossensibilizadores clorina e6 e azul de metileno associados a nanopartículas de ouro sintetizadas por ablação a laser / Aline Magalhães dos Santos; orientadora: Sônia Renaux Wanderley Louro. -2018.

64 f.: il. color. ; $30 \mathrm{~cm}$

Dissertação (mestrado) - Pontifícia Universidade Católica do Rio de Janeiro, Departamento de Física, 2018.

Inclui referências bibliográficas.

1. Física - Dissertações. 2. Biofísica.

3. Fotossensibilizadores. 4. Terapia Fotodinâmica (PDT).

5. Nanopartículas de Ouro. 6. Espectrofotometria I. Louro, Sônia. II. Pontifícia Universidade Católica do Rio de Janeiro. Departamento de Física. III. Título. 


\section{Agradecimentos}

Primeiramente agradeço aos meus pais pela vida, dedicação, conselhos, apoio, por estarem sempre comigo mesmo que distantes. À minha família, aqueles que escolhi e fui acolhida para estar perto, pelas nossas conversas e almoços na casa do vovô, vocês fazem toda diferença na minha vida!

Agradeço à professora Sônia, minha orientadora de mestrado, que me aceitou como aluna mesmo prestes a se aposentar, domou cada ideia maluca minha e corrigiu até meus erros de crase! Muito obrigada pelo grande aprendizado levarei comigo com carinho! Às minhas antigas orientadoras, Simone e Mariana, pela base durante a ic, essa bagagem me ajudou muito nessa nova jornada.

Aos professores que tive na PUC, em especial os professores Tommaso, pela coorientação, Cremona, pelos suportes em laboratório, Marcelo, por me apresentar a PUC, Carla e Welles, pelos conselhos sobre vida profissional. À professora Ana Pavani pela oportunidade de trabalhar na Maxwell e pelos colegas Vanessa, Daniel, Fred, Letícia, Anderson, Maura, Haydee, Carol, Giselen que fizeram desse trabalho uma atividade bastante prazerosa. Ao doutorando Tahir pelas medidas com nanopartículas. Aos técnicos João Manoel e Fredy pelo suporte (socorro) no laboratório e também aos funcionários Giza, Juliana, Eduardo, Marcia, Julinho e Miriam que dão aquele suporte para os alunos aqui no departamento.

Aos meus alunos que, como eles dizem, são "brabos", a parceria Instituto Pró-Saber e Sesi Matemática e ao Lucas e Marco que, além da amizade, fizeram esse projeto nascer.

À Ana, Tita e Mari por me mostrarem que posso superar desafios a cada semana! E, claro, aos colegas e amigos que suportaram minhas besteiras e muitas vezes meu estresse! Obrigada por cada resgate para um café, pelas compras de chocolate e pipoca ou pelas simples conversas de horas quando estávamos sem tempo!

Agradeço ao CNPq e CAPES por todo o apoio financeiro investido nos meus estudos e nesse projeto.

Fica aqui meu muito obrigada a todos! 


\section{Resumo}

Santos, Aline Magalhães; Louro, Sônia Renaux Wanderley (Orientadora). Atividade fotodinâmica dos fotossensibilizadores clorina e6 e azul de metileno associados a nanopartículas de ouro sintetizadas por ablação a laser. Rio de Janeiro, 2018. 64p. Dissertação de Mestrado - Departamento de Física, Pontifícia Universidade Católica do Rio de Janeiro.

Terapia fotodinâmica (PDT) é um tratamento médico baseado na excitação ótica de um fármaco chamado fotossensibilizador. Quando os fotossensibilizadores são expostos a luz em comprimento de onda específico, eles podem produzir espécies reativas, como oxigênio singlete, capazes de matar células próximas ao local irradiado, tais como células cancerígenas. Nanomateriais híbridos formados de nanopartículas metálicas e componentes poliméricos são investigados por seu potencial em aplicações biomédicas devido à sua habilidade de simultaneamente permitir detecção para diagnóstico e terapia (teranóstico). Graças à multifuncionalidade assegurada pelas propriedades plasmônicas das nanopartículas metálicas e atividade terapêutica dos nanotransportadores de drogas, o encapsulamento de nanopartículas de ouro (AuNPs) envolvidas por polímeros biocompatíveis se tornaram um caminho fascinante para testar a terapia fotodinâmica, com a grande vantagem de prevenir efeitos de agregação em condições biológicas. Essa dissertação tem enfoque na estabilização e atividade fotodinâmica de um nanomaterial híbrido constituído de AuNPs sintetizadas em água por ablação a laser pulsado. O copolímero Pluronic F-127 foi utilizado como componente polimérico para estabilizar as nanopartículas. A produção de oxigênio singlete pelos fotossensibilizadores clorina e6 e azul de metileno foi estudada em ausência e em presença das AuNPs, utilizando 1,3-difenilisobenzofurano (DPBF) como sonda molecular. A reação específica de DPBF com oxigênio singlete modifica seu espectro de absorção na faixa visível, permitindo obter taxas de produção da espécie citotóxica. As amostras foram irradiadas com um LED emitindo em $650 \mathrm{~nm}$ e os espectros de absorção foram monitorados como função do tempo durante a irradiação. Foram obtidas taxas de fotodegradação dos fotossensibilizadores e rendimento quântico de produção de oxigênio singlete nos diferentes casos. 


\section{Palavras-chave}

Biofísica; Fotossensibilizadores; Terapia fotodinâmica (PDT);

Nanopartículas de ouro; Espectrofotometria 


\section{Abstract}

Santos, Aline Magalhães; Louro, Sônia Renaux Wanderley (Advisor) Photodynamic activity of chlorin e6 and methylene blue photosensitizers associated with gold nanoparticles synthesized by laser ablation. Rio de Janeiro, 2018. 64p. Departamento de Física, Pontifícia Universidade Católica do Rio de Janeiro.

Photodynamic therapy (PDT) is a medical treatment based on the optical excitation of a drug, called photosensitizer. When photosensitizers are exposed to light of specific wavelength, they can produce reactive species, such as singlet oxygen, capable of killing cells close to the irradiated site, such as cancer cells. Hybrid nanomaterials, comprising metallic nanoparticles and polymeric components, are investigated for their potential in biomedical applications due to their ability to simultaneously allow detection for diagnosis and therapy (theranostic). Thanks to the multi functionality assured by the nanoparticle plasmonic properties and therapeutic activity of the drug nanotransporters, the encapsulation of gold nanoparticles (AuNPs) wrapped by biocompatible polymers has become an attractive way to test photodynamic therapy, with the great advantage of preventing effects of aggregation under biological conditions. This dissertation focuses on the stabilization and photodynamic activity of a hybrid nanomaterial composed of AuNPs synthesized in water by laser ablation. The copolymer Pluronic F-127 was used as a polymeric component to stabilize the nanoparticles. The production of singlet oxygen by the photosensitizers chlorin e6 and methylene blue was studied in the absence and presence of AuNPs using 1,3 diphenylisobenzofuran (DPBF) as a molecular probe. The specific reaction of DPBF with singlet oxygen modifies its absorption spectrum in the visible range and allows to obtain rates of cytotoxic species production. Samples were irradiated with a LED emitting $650 \mathrm{~nm}$ radiation and the absorption spectra were monitored as a function of time during irradiation. Rates of photosensitizers'degradation and quantum yields of singlet oxygen production were obtained in different cases.

\section{Keywords}

Biophysics; Photosensitizer; Photodynamic therapy (PDT); Gold nanoparticles; Spectrophotometry 


\section{Sumário}

1 Introdução 14

1.1. A Terapia Fotodinâmica 14

1.2. Fotossensibilizadores 15

$\begin{array}{ll}\text { 1.2.1. Clorina e6 } & 17\end{array}$

$\begin{array}{ll}\text { 1.2.2. Azul de Metileno } & 18\end{array}$

1.3. Nanopartículas de Ouro e Teranóstico 20

1.4. Pluronic F-127 22

1.5. A sonda difenilisobenzofurano (DPBF) 23

1.6. Objetivo 24

2 Técnica 26

2.1. Absorção 26

2.2. Lei de Beer Lambert 28

2.3. Absorção e processos de desexcitação 29

3 Materiais e métodos 31

3.1. Materiais utilizados 31

3.2. Preparação das amostras 32

3.3. Procedimento Experimental 33

4 Resultados e Discussão 36

4.1. Influência de AuNPs na produção de ${ }^{1} \mathrm{O}_{2}$ por Clorina e6 40

4.2. Influência de AuNPs na produção de ${ }^{1} \mathrm{O}_{2}$ por Azul de Metileno 46

5 Conclusão 56

6 Referências bibliográficas 58

7 Apêndice 63 


\section{Lista de Figuras}

Figura 1.1. Esquema dos mecanismos I e II de decaimento (Ribeiro et al., 2007)

Figura 1.2. Estrutura molécular do fotossensibilizador clorina e6 (Ce6).

Espectro de absorção de Ce6 e Ce6 hidrogenada em DMSO (modificado de DOI: 10.1039/C3PP50376C, Photochem. Photobiol. Sci., 2014, 13, 1137-1145)

Figura 1.3. Estrutura molecular do fotossensibilizador azul de metileno (MB). Espectro de absorção de MB (modificada de DOI: 10.1016, Vacuum, 126.63-69. 2016 )

Figura 1.4. (A) Esquema do efeito de ressonância plasmônica das nanopartículas e (B) espectros de extinção de nanopartículas de ouro de diferentes tamanhos (modificado de Huang e El-Sayed, 2010)

Figura 1.5 Nano partículas de ouro não aglomeradas (A) e aglomeradas (B) em solução e seus espectros de densidade óptica mostrando o desvio para o vermelho

Figura 1.6. Molécula do copolímero tribloco pluronic F127

Figura 1.7. Esquema de formação de micelas de Pluronic na presença de porfirinas (Zhientaev et al., 2009): (a) Porfirina insolúvel em água localizada centro hidrofóbico e (b) Porfirina hidrofílica na superfície hidrofílica micelar

Figura 1.8. Molécula da sonda DPBF

Figura 1.9. Esquema representativo das nanopartículas com o fotossensibilizador na presença de luz emitindo oxigênio singlete e atuando no tratamento contra fungos, bactérias e tumores

Figura 2.1. Diagrama representando as transições verticais, onde a linha azul indica absorção e a verde, emissão. O nível de energia $E_{0}$ representa o estado eletrônico fundamental e $E_{1}$, o primeiro estado eletrônico excitado. Os níveis v são níveis vibracionais

Figura 2.2. Esquema da representação dos spins nos estados singlete (fundamental e excitado) e estado excitado triplete 
Figura 2.3. Esquema representativo da absorção da luz por uma amostra em função da distância $l$ percorrida pela luz no interior da amostra. Figura adaptada (Galo e Colombo, 2009)

Figura 2.4. Diagrama de Jablonski e associação das posições relativas dos espectros de absorção, fluorescência e fosforescência

Figura 3.1: Ouro posicionado durante a ablação a laser (esquerda) e amostras de nanopartículas não aglomeradas em água (direita)

Figura 3.2 Equipamento espectrofotômetro UV/VIS Perkin Elmer modelo Lambda 950

Figura 3.3. Espectro do LED utilizado para irradiar as amostras.

Figura 3.4: Espectro de transmitância do filtro C3C22 feito pelo doutorando Rian Aderne sob orientação do professor Marco Cremona 34 Figura 3.5: Esquema de montagem experimental dentro e fora do compartimento de amostras do espectrofotômetro. A) o LED posicionado de frente para a cubeta; B) o circuito controlado do LED do lado de fora e $\mathrm{C}$ ) a montagem com o filtro

Figura 4.1 (a) Estrutura molecular da clorina e6 e seu espectro de absorção óptica. (b) Estrutura molecular do azul de metileno e seu espectro de absorção óptica

Figura 4.2. Espectro de absorção de $30 \mu \mathrm{M}$ DPBF em água

Figura 4.3. Espectros de extinção das nanopartículas aglomeradas (AuNP+NaCl) e não aglomeradas (AuNP) logo após a síntese, com adição de Pluronic F-127.

Figura 4.4. (a) Espectros de absorção da sonda DPBF na presença de $1 \mu \mathrm{M}$ de clorina e6 em tampão fosfato. (b) b Espectro de absorção da

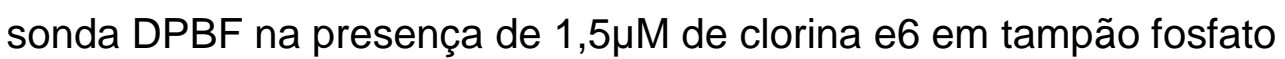
Figura 4.5. Espectros de absorção da sonda DPBF na presença

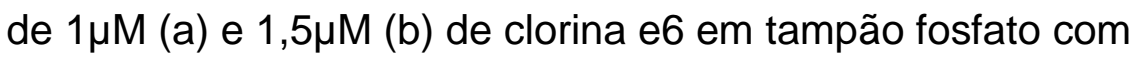
nanopartículas de ouro não aglomeradas estabilizadas com Pluronic F-127

Figura 4.6. Espectros de absorção da sonda DPBF em (a) clorina e6 1,0 $\mu \mathrm{M}$ e (b) clorina e6 1,5 $\mu \mathrm{M}$ ambas em nanopartículas de ouro aglomeradas estabilizadas com PF-127 em tampão. 
Figura 4.7: Decaimento da absorção do DPBF em amostras de nanopartículas aglomeradas ( $A u N P_{a g}$ ) e não aglomeradas (AuNP) com diferenctes concentrações de clorina e6 $(1,0 \mu \mathrm{M}$ e 1,5 $\mu \mathrm{M})$ em função do tempo de irradiação

Figura 4.8. ( $\left.A_{0}-A\right)$ em $418 \mathrm{~nm}$ normalizado pela concentração de Ce6 como função do tempo. [Ce6] foi obtida da absorbância da clorina em $402 \mathrm{~nm}$.

Figura 4.9 Decaimento de DPBF $(30 \mu \mathrm{M})$ apenas em solução de tampão fosfato $10 \mathrm{mM}, \mathrm{pH} \mathrm{7,4.}$

Figura 4.10 Decaimento de DPBF $30 \mu \mathrm{M}$ em solução tampão fosfato $10 \mathrm{mM}, \mathrm{pH} 7,4$, e azul de metileno $2 \mu \mathrm{M}$.

Figura 4.11 Decaimento de DPBF $30 \mu \mathrm{M}$ em solução com $0,8 \mathrm{mg} / \mathrm{ml}$ de Pluronic F-127, $2 \mu \mathrm{M}$ de azul de metileno em tampão fosfato $10 \mathrm{mM}$

Figura 4.12. Decaimento da absorção de DPBF no comprimento de onda 418 nm em função do tempo de irradiação.

Figura 4.13. Variação da absorção de $\operatorname{DPBF}\left(\triangle A=A_{0}-A\right)$ no comprimento de onda $418 \mathrm{~nm}$ em função do tempo de irradiação.

Figura 4.14. Decaimento da absorção no comprimento de onda $664 \mathrm{~nm}$ (referente ao pico de absorção do azul de metileno) em função do tempo.

Figura 4.15. Decaimento do espectro de absorção de (a) DPBF em azul de metileno $2 \mu \mathrm{M}$ sob iluminação com LED de $650 \mathrm{~nm}\left(\mathrm{~A}_{664}=0,042\right)$ (Houve alguma reação que modificou o espectro de DPBF) (b) DPBF $30 \mu \mathrm{M}$ em AuNP + PF127 0,3mg/ml + MB 2 $\mu \mathrm{M}\left(\mathrm{A}_{660}=0,02 \mathrm{MB}\right)$

Figura 4.16. Decaimento do DPBF em AuNPag2 $+0,3 \mathrm{mg} / \mathrm{ml}$ $+2 \mu \mathrm{M}$ de $\mathrm{MB}+30 \mu \mathrm{M}$ DPBF

Figura 4.17. Decaimento da absorção do DPBF em função do tempo de iluminação, no comprimento de onda $416 \mathrm{~nm}$ para as quatro amostras medidas.

Figura 4.18. Variação da absorção de $\operatorname{DPBF}\left(\triangle A=A_{0}-A\right)$ no comprimento de onda $416 \mathrm{~nm}$ em função do tempo de irradiação.

Figura 7.1 a) Esquema elétrico do circuito e b) o desenho para impressão do circuito controlador da intensidade do LED 


\section{Lista de Abreviações}

$\begin{array}{ll}A(\lambda) & \text { Absorbância } \\ \text { AuNP } & \text { Nanopartícula de Ouro } \\ \text { AuNPa } & \text { Nanopartículas de Ouro aglomeradas } \\ \mathrm{Cl} & \text { Conversão Interna } \\ \text { CIS } & \text { Cruzamento Intersistemas } \\ \text { DPBF } & 1,3 \text { difenilisobenzofurano } \\ \text { FS } & \text { Fotossensibilizador } \\ \text { I } & \text { Intensidade da luz } \\ \text { LED } & \text { Light Emitting Diode } \\ \text { LSPR } & \text { Ressonância de Plásmon de Superfície Localizado (do } \\ & \text { inglês, Localized Surface Plasmon Resonance) } \\ { }^{1 O}{ }_{2} & \text { Oxigênio singlete } \\ \text { PB } & \text { Tampão fosfato (do inglês, phosphate buffer) } \\ \text { PF-127 } & \text { Pluronic F-127 } \\ \text { PDT } & \text { Terapia Fotodinâmica (do inglês, PhotoDynamic Therapy) } \\ \text { ROS } & \text { Espécies reativas de oxigênio (do inglês, Reactive Oxygen } \\ & \text { Species) } \\ \text { So } & \text { Estado singlete fundamental } \\ \text { S } 1 & \text { Estado singlete excitado } \\ \mathrm{T}_{1} & \text { Estado triplete }\end{array}$


-A abelha vai na plantinha e pega o pólen, aí quando o papai abre a caixa tem mel! -E como a abelha faz o mel, Pedro?

-Ela cozinha, ué! Pedro Félix 


\section{Introdução}

1.1.

A Terapia Fotodinâmica

A Terapia fotodinâmica (PDT) é um tratamento que combina o uso de um fármaco fotossensibilizador e luz em um comprimento de onda particular. Quando os fotossensibilizadores são expostos a essa luz, eles podem produzir oxigênio singlete que matam as células próximas através da necrose ou apoptose do tecido ou as inviabilizam no caso dos fungos, bactérias, vírus e células cancerígenas. (Machado, 1999).

Tem-se registro de que compostos fotossensíveis são utilizados há mais de 3500 anos ao se utilizarem ervas medicinais na presença de luz, como nos papiros Ebers (tratado médico escrito no antigo Egito) e no livro indiano sagrado Atharva Veda, onde na época o tratamento era indicado para pessoas com lesões na pele, algo semelhante a lepra. Plantas contendo fotossensibilizadores citadas como tratamento para vitiligo são descritas em livros chineses do século 10. No livro egípcio Monfradat Al Adwiya, o médico e botânico Ibne al Baitar descreve o tratamento de lesões na pele com o uso de mel e semente de aatrillal (amni majus) em pó (Radaev). Estes são exemplos de como os efeitos da atividade fotodinâmica já eram observados e utilizados, mas ainda não se tinha conhecimento do por que ou como funcionava.

Em 1900, através do tratamento de uma suspensão de paramécio, um protozoário, o ainda estudante de medicina Oscar Raab observou a morte de microorganismos quando expostos a luz e nenhum efeito na ausência de iluminação. Descrito por von Tappenier, seu orientador, o efeito começou a ser testado em humanos em 1903 pelo próprio Tappenier e Jesionek utilizando o corante vermelho eosina (Borissevitch \& Ferreia, 2016 e Machado, 2000), no mesmo ano o médico dinamarquês Niels Ryberg Finsen ganhou o prêmio Nobel em fisiologia ou medicina "em reconhecimento a contribuição no tratamento de doenças, especialmente lupus vulgaris, com base em aplicação da luz visível, 
através da qual abriu uma nova via para a ciência médica" dando início a terapia fotodinâmica. Em 1912 o médico alemão Friedrich Meyer Betz aplicou nele mesmo $200 \mathrm{mg}$ de um derivado de hematoporfirina, assim também constatou que na ausência de luz não se obtinha efeito, mas na exposição a luz solar apresentou agressões à pele como edemas e erupções.

Nos anos 70, a terapia fotodinâmica passou a ter reconhecimento para tratamento do câncer e outras condições clínicas graças a Dougherty e colaboradores através de pesquisas sobre terapia por fotoirradiação para o tratamento de tumores malignos no Roswell Park Cancer Institute (Buffalo-NY). O tratamento chegou a 113 casos de tumores malignos cutâneos e subcutâneos com um derivado de hematoporfirina e observou a redução total ou parcial de 111 tumores (Dougherty et al, 1978). Nos anos 80, John Toth, gerente de produtos da Cooper Medical Devices, notou o "efeito químico fotodinâmico" da terapia e escreveu o primeiro artigo utilizando o termo "Terapia fotodinâmica (PDT)" com os primeiros lasers clínicos de argônio. A empresa montou dez locais de tratamento no Japão, mas o uso do termo "radiação" teve conotação negativa. Em 1993 o tratamento para tumores de pulmão e pescoço foi aprovado no FDA (U.S. Food \& Drug Administration)

Alguns tratamentos já possuem resultados positivos em humanos, tais como melanoma (Wagner et al., 2012), sarcoma de kaposi (Tardivo et al., 2006), candidíase (Scwingel et al., 2012), descontaminação de doenças no sangue (Wainwright, 2000), Leishmaniose e doenças tropicais (Song et al.,2011), lesões pelo vírus da herpes.

\section{2.}

\section{Fotossensibilizadores}

São substâncias que podem ser absorvidas pelo tecido e são de baixa toxicidade na ausência de luz, mas na irradiação com luz em comprimentos de onda específicos produzem estados eletronicamente instáveis que podem decair de algumas formas conhecidas como mecanismo tipo I e mecanismo tipo II, que aparecem apresentadas no esquema da Figura 1.1.

O mecanismo tipo I descreve processos que envolvem reações que formam espécies radicalares ou peróxidos, através de transferência de elétrons entre 
moléculas do fotossensibilizador (FS) no seu estado excitado $F S\left(S_{1}^{*}\right)$ ou $F S\left(T_{1}^{*}\right)$ e a solução, formando íons -radicais que tendem a reagir com oxigênio molecular resultando em produtos oxidados.

$$
\begin{array}{r}
F S\left(S_{1}^{*} \text { ou } T_{1}^{*}\right)+A_{0} \rightarrow\left[F S^{-\cdot} . . . A^{+\cdot}\right] \rightarrow F S^{-\cdot}+A^{+\cdot}+O_{2} \\
\rightarrow F S\left(S_{0}\right)+A^{+\cdot}+O_{2}^{-\cdot} \rightarrow A O_{2} \text { (Produto oxidado) }
\end{array}
$$

Já no mecanismo tipo II a energia do estado triplete do fotossensibilizador $F S\left(T_{1}^{*}\right)$ é transferida para a molécula de oxigênio. Nesse processo o FS volta ao estado fundamental $S_{0}$ e o oxigênio vai para seu estado excitado singlete, chamado como oxigênio singlete.

$$
F S\left(T_{1}^{*}\right)+O_{2}\left(T_{1}\right) \rightarrow F S\left(S_{0}\right)+O_{2}\left(S_{1}^{*}\right)
$$

Nesse mecanismo o oxigênio formado é bastante reativo a possíveis ataques a tecidos biológicos levando a possível destruição celular.

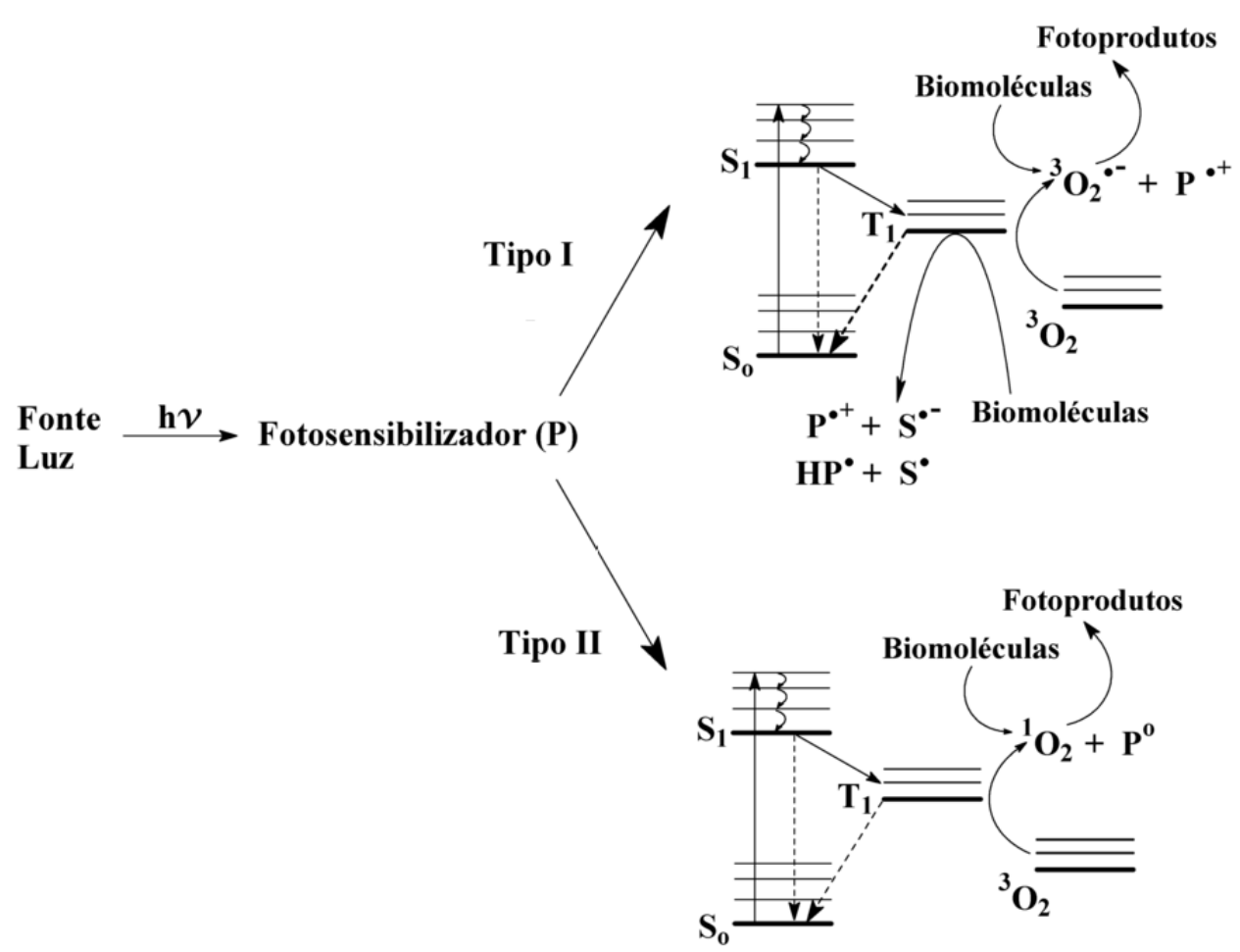

Figura 1.1. Esquema dos mecanismos I e II de decaimento (Ribeiro et al., 2007)

Nos dois mecanismos são geradas espécies reativas de oxigênio (ROS) sendo a produção de oxigênio singlete (mecanismo tipo II) o mais relevante nos tratamentos envolvendo terapia fotodinâmica (PDT). 
A luz empregada deve, preferencialmente, ter comprimento de onda na janela terapêutica, aproximadamente entre 600 e 1000 nm, que é a região com maior penetração no tecido humano (Dougther, T.H.; et al. 1977 \& Bonnet. R.; 1995), o que possibilita atingir fotossensibilizadores em regiões mais profundas ente 5 e $20 \mathrm{~mm}$ sem tratamento invasivo (Oliveira, 2015).

É de interesse clínico que os fotossensibilizadores apresentem algumas características como: ser seletivo para a região a ser tratada, como tumores, possuir absorção e acumulação rápida na região a ser tratada, permanência na região por tempo suficiente para o tratamento, mas com eliminação rápida pelo organismo, para que o paciente possa retornar a suas atividades, sem a necessidade de quarentena.

Para nosso trabalho, utilizamos dois fotossensibilizadores: clorina e6 e azul de metileno.

\subsection{1.}

\section{Clorina e6}

A clorina e6 é utilizada em estudos envolvendo terapia fotodinâmica por ser um fotosenssibilizador que absorve luz na região conhecida como janela terapêutica, que abrange comprimentos de onda de $600 \mathrm{~nm}$ a $800 \mathrm{~nm}$, produzindo radicais citotóxicos.

$\mathrm{Na}$ ausência de luz a susbstância não é tóxica. A estrutura molécular da clorina e6 e seu espectro de absorção UV-Visível são apresentados na Figura 1.2.

As clorinas são derivadas de porfirina, uma classe de substâncias orgânicas de estrutura tetrapirrólicas por possuírem em quatro anéis pirrólicos (que são estruturas heterocíclicas formadas de carbono, hidrogênio e nitrogênio) ligados por uma ligação simples entre carbono e hidrogênio (-CH-) possibilitando a ligação de um íon metálico em seu centro (Nelson e Cox 2014) (Figura 1.2). Essa classe de fotossensibilizantes, em geral, possui uma banda de absorção de maior intensidade na região de $400 \mathrm{~nm}$, denominada banda Soret, e outras de menor intensidade localizadas em comprimentos de onda maiores, de $500 \mathrm{~nm}$ a $650 \mathrm{~nm}$, região conhecida como banda Q (Figura 1.2). 

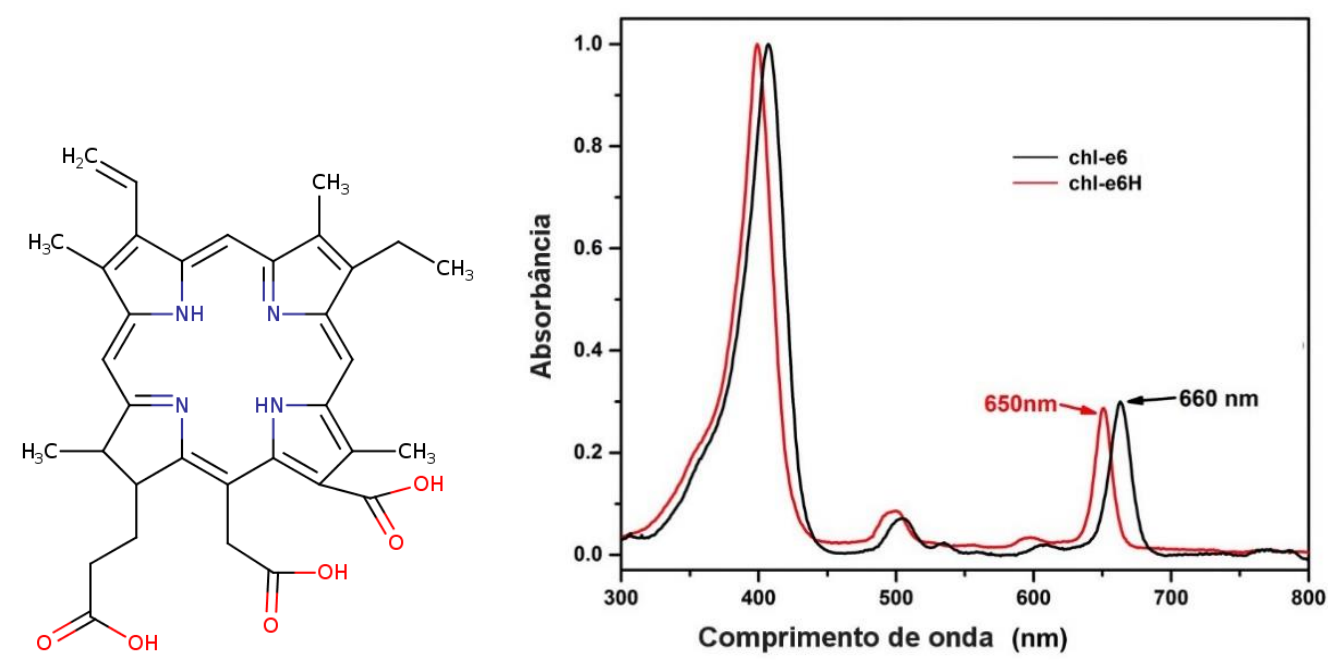

Figura 1.2. Estrutura molécular do fotossensibilizador clorina e6 (Ce6). Espectro de absorção de Ce6 e Ce6 hidrogenada em DMSO (modificado de DOI: 10.1039/C3PP50376C, Photochem. Photobiol. Sci., 2014, 13, 1137-1145)

Apesar das porfirinas e clorinas terem muitas semelhanças, a redução de um anel pirrol provoca uma alteração na simetria da molécula dando origem a alterações de grande importância para as aplicações destas substâncias em PDT (Cunderlikova et al 1999). As clorinas absorvem fortemente na região do azul e do vermelho no espectro de UV-Vis, enquanto que as porfirinas absorvem fortemente na região do azul. Essa diferença é fácil de ser observada visto que é o que faz com que a cor das porfirinas seja vermelha e das clorinas verde.

A absorção no vermelho, importante característica dos fotossensibilizadores de $2^{\text {a }}$ geração, faz com que as clorinas se destaquem, como por exemplo, os derivados sintéticos já introduzidos no mercado, Foscan ${ }^{\circledR}$, Photochlor ${ }^{\circledR}$ e o Photodithazine®, sendo esse último já em fase final de testes para aplicação em Terapia Fotodinâmica (Calvete, M. et al 2009) .

Para nosso trabalho, a clorina e6 foi escolhida como fotossensbilizador por possuir em seu espectro de absorção um pico em $650 \mathrm{~nm}$, região do vermelho e dentro da janela terapêutica.

\subsection{2.}

\section{Azul de Metileno}

O fotossensibilizante azul de metileno é uma molécula heterocíclica catiônica (Figura1.3) derivada da molécula de fenotiazina, que por sua vez é derivada de tiazina, um composto aromático utilizado como corante, tranquilizante e até mesmo 
inseticida. Assim como a clorina, o azul de metileno também é utilizado no tratamento de infecções bacteriológicas e doenças tropicais, como agente desinfetante para o sangue e como fotossensibilizador no tratamento e estudos envolvendo terapia fotodinâmica (de Souza et al 2017).

Possui em seu espectro de absorção picos na região do ultravioleta, $245 \mathrm{~nm}$ e 290 nm, e de máxima absorção na região do vermelho, em 664,5 nm (Figura 1.3), o que faz o azul de metileno ser utilizado na área da saúde por também absorver na região da janela terapêutica.<smiles>CN(C)c1ccc2nc3ccc(N(C)C)cc3[s+]c2c1</smiles>

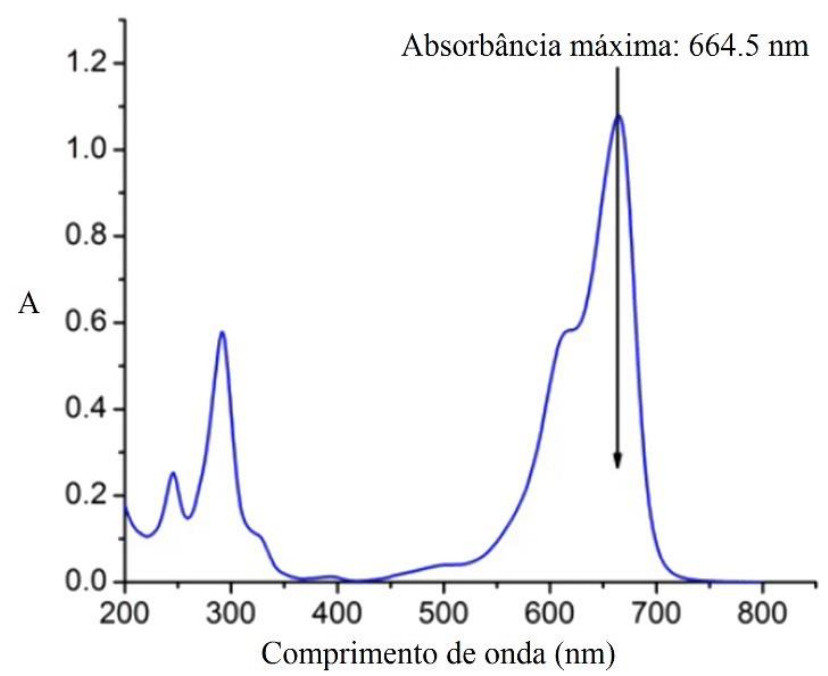

Figura 1.3. Estrutura molecular do fotossensibilizador azul de metileno (MB). Espectro de absorção de MB (modificada de DOI: 10.1016, Vacuum, 126.63-69. 2016 )

Em estudos celulares, cientistas observaram que sua localização no interior das células é nos lisossomos (Mellish et al, 2002 e de Souza et al, 2017), indicando a preferência da molécula não apenas pelo meio intracelular como pela posição específica. Podendo ser utilizado também como marcador ou bom carregador, no caso de liberação controlada de fármacos.

O azul de metileno foi escolhido para nosso trabalho por ser um fotossensibilizador com banda de absorção na região do vermelho, região de boa absorção pelo tecido humano, e nenhuma absorção considerável na região entre $350 \mathrm{~nm}$ e $450 \mathrm{~nm}$, onde se encontra o pico de absorção da nossa sonda sensível a produção de oxigênio singlete, DPBF, tornando possível uma análise mais direta. 


\section{3. Nanopartículas de Ouro e Teranóstico}

As nanopartículas têm se tornado foco de muitas pesquisas devido às mudanças das propriedades dos materiais quando reduzidos a escala nanométrica. Essas propriedades abrangem uma gama de aplicações na área biomédica como imagem celular, diagnóstico molecular e terapias dependendo da composição, forma e estrutura desses nanomateriais. As nanopartículas metálicas se destacam devido a propriedades de condução, magnéticas e de ressonância plasmônica de superfície (LSPR) (Huang\& El-Sayed, 2010). As de ouro foram escolhidas por sua biocompatibilidade e banda de ressonância plasmômica na região de absorção do corpo humano (del Rosso et al, 2018).

O efeito de ressonância de plasmon de superfície localizado (LSPR) das nanopartículas metálicas é devido a um conjunto de oscilações dos elétrons livres (elétrons da banda de condução) induzido pelo campo eletromagnético da luz incidente. A oscilação dos elétrons causa uma separação de cargas na superfície das nanopartículas metálicas formando um dipolo que também oscila na direção de oscilação do campo elétrico da luz, esquematizado na Figura 1.4 A, onde $E$ é a direção de oscilação do campo elétrico e $k$, o vetor de onda desse campo. A amplitude de oscilação possui máximos em frequências específicas, chamadas de ressonância de plásmons de superfície localizados (LSPR). O efeito de LSPR pode ser observado através do espectro de extinção das nanopartículas como uma banda característica que depende de uma série de fatores como material, tamanho, forma etc. A Figura 1.4 B mostra o efeito observado em um espectro de extinção das nanopartículas. Conforme o tamanho das nanopartículas aumenta, vemos a banda de absorção sendo deslocada para comprimentos de ondas também maiores. A teoria por trás do aparecimento da banda foi descrita por Mie (Mie, 1908), na qual, para nanopartículas com até $20 \mathrm{~nm}$ temos a seguinte equação:

$$
C_{\text {ext }}=\frac{24 \pi^{2} R^{3} \varepsilon_{m}^{3 / 2}}{\lambda} \frac{\varepsilon_{\mathrm{i}}}{\left(\varepsilon_{r}+2 \varepsilon_{m}\right)^{2}+\varepsilon_{i}^{2}}
$$

onde $C_{e x t}$ é a seção de choque, que é relacionada ao coeficiente de extinção por $\varepsilon\left(M^{-1} \mathrm{~cm}^{-1}\right)=10^{-3} N_{0} C_{e x t}\left(\mathrm{~cm}^{2}\right) / 2.303, \lambda$ é o comprimento de onda da luz incidente, $\varepsilon$ é a constante dielétrica complexa do metal, dada por $\varepsilon=\varepsilon_{r}(\omega)+$ $i \varepsilon_{i}(\omega)$, onde $\varepsilon_{r}$ é a parte real e $\varepsilon_{i}$ é a parte imaginária e $\varepsilon_{m}$ é a constante dielétrica 
do meio em que está a nanopartícula. $\mathrm{O}$ efeito de ressonância ocorre quando $\varepsilon_{r}(\omega)=-2 \varepsilon_{m}$, a chamada condição de Fröhlich. O que observamos no espectro de extinção das nanopartículas é a parte real da constante dielétrica do metal, determinando a posição da banda, e a parte imaginária, sua largura.

A

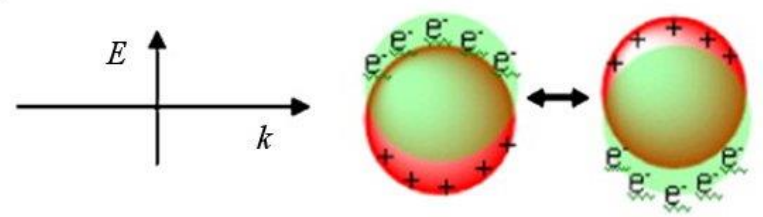

B

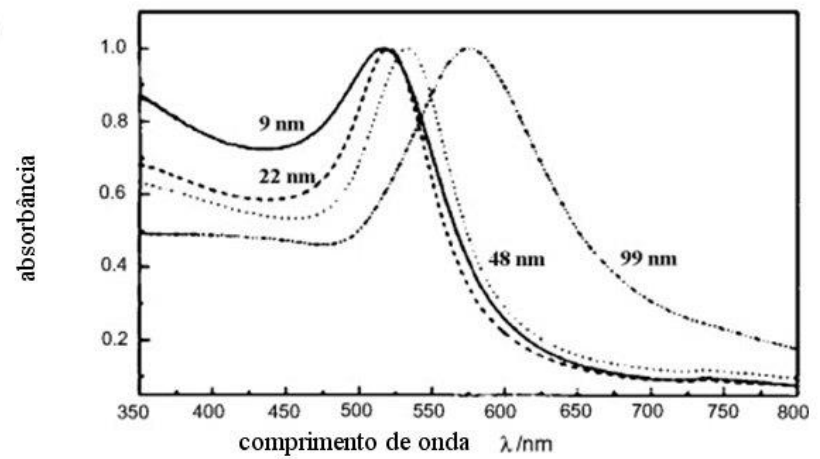

Figura 1.4. (A) Esquema do efeito de ressonância plasmônica das nanopartículas e (B) espectros de extinção de nanopartículas de ouro de diferentes tamanhos (modificado de Huang e El-Sayed, 2010).

Para nanopartículas de ouro (AuNP) a banda de LSPR se encontra em comprimentos de onda em torno de $520 \mathrm{~nm}$ para partículas de tamanhos menores que $10 \mathrm{~nm}$. Conforme o tamanho das nanopartículas aumenta, é possível observar um deslocamento da banda para o vermelho (Figura 1.4 e 1.5). Essa mudança no espectro de extinção das nanopartículas metálicas também pode ser observada com a alteração da coloração da solução onde elas estão imersas (Figura 1.5).
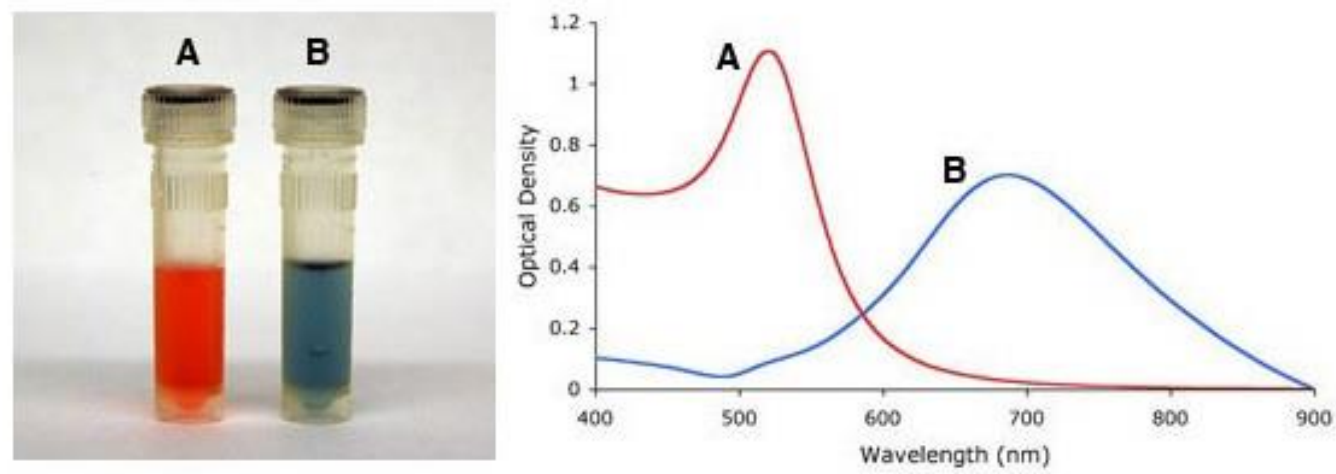

*http:/www.cytodiagnostics.com/store/pc/Introduction-to-Gold-Nanoparticle-Characterization-d3.htm

Figura 1.5 Nano partículas de ouro não aglomeradas (A) e aglomeradas (B) em solução e seus espectros de densidade óptica mostrando o desvio para o vermelho. 
Graças a sua multifuncionalidade assegurada pelas propriedades plasmônicas e atividade terapêutica dos "nanoportadores de drogas" (Simon et al., 2015), o encapsulamento de nanopartículas de ouro (AuNP) em camadas poliméricas biocompatíveis tem se tornado uma interessante alternativa no uso da terapia fotodinâmica, com sua larga vantagem de prevenir os efeitos de agregação sob condições biológicas (Zhou et al., 2009). Esses nanomateriais híbridos, compostos de nanopartículas metálicas e polímero, são investigados por terem potencial em aplicações biomédicas devido a sua habilidade de permitir, simultaneamente, detecção, diagnóstico e terapia (Vivero-Estoco \& Huang, 2011).

Para nosso trabalho, utilizamos como camada polimérica o recobrimento das nanopartículas com o polímero Pluronic F-127.

\section{4. Pluronic F-127}

Os copolímeros Pluronic têm sido utilizados na estabilização de nanopartículas por serem, além de biocompatíveis, copolímeros tribloco de estrutura molecular anfifílica. Sua cadeia de três blocos de polímeros possui a parte central (polioxipropileno) diferente das dos extremos (polioxietileno), gerando assim uma sequência hidrofílica-lipofílica-hidrofílica (Figura 1.6), o que é favorável para a formação de micelas em solução aquosa. Os códigos no fim do nome se referem as características do polímero quando estão puros, a letra indicando se é F - Flocos, $\mathrm{P}$ - Pasta ou L - Líquido e os dígitos correspondem ao grau de polimerização (dígitos iniciais) e o último, a porcentagem em peso da molécula central (Solovieva et al., 2009)

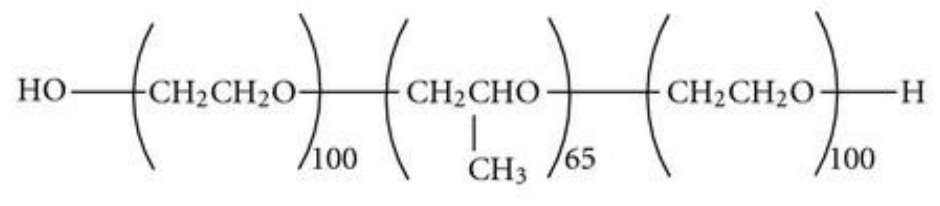

Pluronic F127

Figura 1.6. Molécula do copolímero tribloco pluronic F127

A formação de micela provoca o encapsulamento das nanopartículas pelo polímero, o que garante a estabilidade, impedindo a agregação das nanopartículas 
e tornando as mais amigáveis para ambientes biológicos. (Abdullin et al., $2009 \&$ Rahme et al., 2008). A Figura 1.7 mostra o esquema da formação de micelas de Pluronic na presença de porfirinas hidrofílicas e hidrofóbicas.

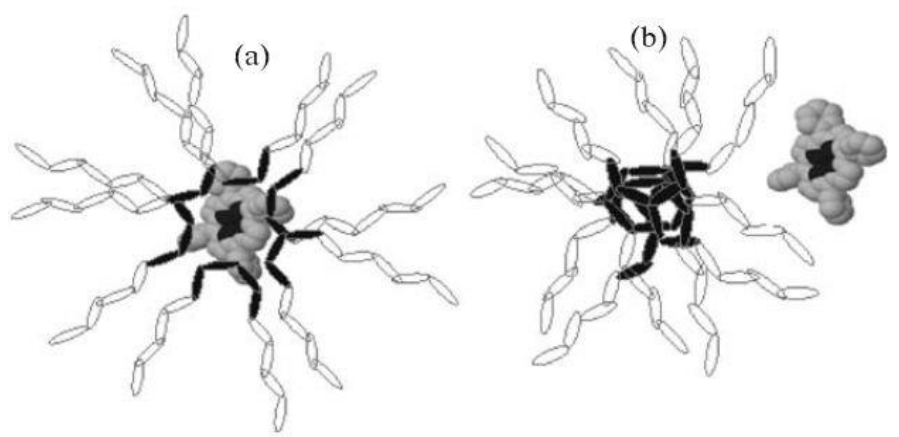

Figura 1.7. Esquema de formação de micelas de Pluronic na presença de porfirinas (Zhientaev et al., 2009): (a) Porfirina insolúvel em água localizada centro hidrofóbico e (b) Porfirina hidrofílica na superfície hidrofílica micelar.

No nosso caso, o recobrimento se dá preferencialmente sobre as nanopartículas, visto que utilizamos a quantidade mínima para a estabilização e, depois de uma noite (tempo suficiente para interação), acrescentamos os fotossensibilizadores e, por fim, a sonda DPBF para detecção do oxigênio singlete.

\section{5.}

\section{A sonda difenilisobenzofurano (DPBF)}

A molécula 1,3-difenilisobenzofurano (DPBF) (Figura 1.8) é uma sonda utilizada para detecção de oxigênio singlete na faixa da luz ultravioleta ao visível.

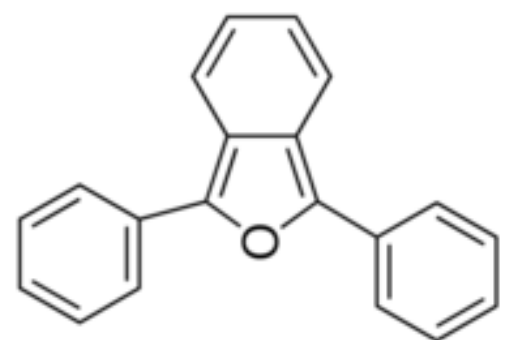

Figura 1.8. Molécula da sonda DPBF

Sua versatilidade inclui ser utilizada em alguns solventes como etanol (etOH), DMF e DMSO, e em técnicas como absorção, fluorescência em estado estacionário e fluorescência resolvida no tempo, bem como em fotólise.

O 1,3-difenilisobenzofurano (DPBF) é uma molécula fluorescente que possui uma reatividade altamente específica para o oxigênio singlete $\left({ }^{1} \mathrm{O}_{2}\right)$ formando um 
peróxido que se decompõe para dar 1,2-dibenzoilbenzeno. Esta reação pode ser seguida medindo a diminuição da intensidade de fluorescência do espectro de absorção do DPBF. A especificidade do DPBF em relação aos radicais livres foi testada em vários experimentos em que DPBF reagiu com radicais hidroxi (HO), alquiloxi (RO'). alquilperoxi (ROO') e radicais C-centrados (radical 2cianoisopropilo) (Carloni et al., 1993). Em todos os casos, verificou-se que o DPBF é transformado em 1,2-dibenzoilbenzeno no caso de radicais O-centrados e no correspondente aduto no caso do radical 2-cianoisopropilo. Então, verificou-se que o DPBF deve ser utilizado com cautela em sistemas biológicos complexos, para a detecção de ${ }^{1} \mathrm{O}_{2}$, pois também reage com diferentes espécies de radicais livres.

É também sabido que o DPBF pode ser degradado mesmo quando exposto a luz de baixa intensidade ou apenas à luz do dia em solventes contendo halogéneo na ausência de oxigênio singlete. O DPBF em etanol (etOH), DMF, DMSO, etc., por outro lado, é estável o suficiente para permitir medidas de absorção e fluorescência. (Xian-Fu Zhang \& Xiaoli Li 2011).

\section{6. \\ Objetivo}

Dentro desse breve contexto, nosso trabalho tem como objetivo a estabilização em ambiente de alta força iônica e a análise da atividade fotodinâmica de um nanomaterial híbrido constituído por fotossensibilizadores (clorina e6 ou azul de metileno) envolvendo as nanopartículas AuNP (aglomeradas e não aglomeradas) sintetizadas por ablação de um alvo de ouro em água (del Rosso et al., 2018), recobertas com o copolímero Pluronic F-127 utilizado como componente polimérico para estabilizar as nanopartículas.

A Figura 1.9 mostra um esquema representativo da produção de oxigênio singlete por fotossensibilizadores ligados a nanopartículas e sua atuação na eliminação de células, vírus ou bactérias indesejadas. Em nosso trabalho, a produção de oxigênio singlete pelos fotossensibilizadores foi estudada na ausência e na presença das AuNPs, utilizando 1,3-difenilisobenzofurano (DPBF) como sonda através da modificação do seu espectro de absorção na faixa do visível. 


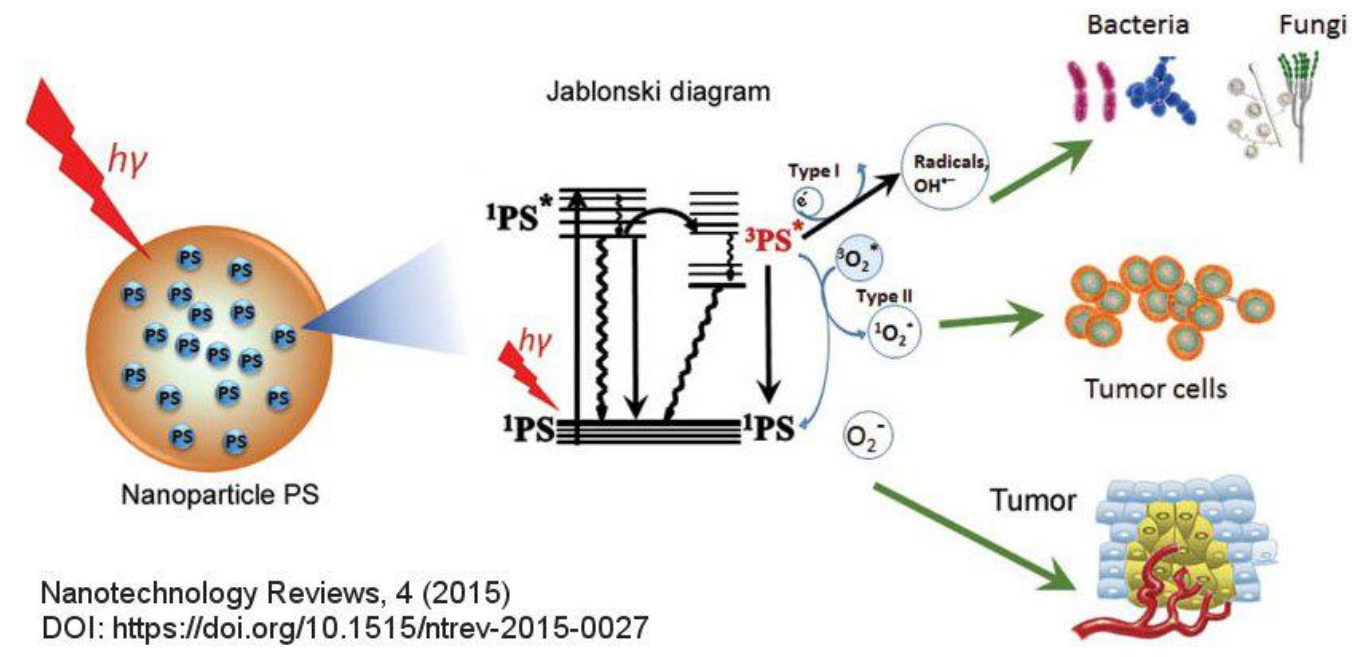

Figura 1.9. Esquema representativo das nanopartículas com o fotossensibilizador na presença de luz emitindo oxigênio singlete e atuando no tratamento contra fungos, bactérias e tumores.

Tal análise de decaimento nos permitiu obter taxas de produção da espécie citotóxica. As amostras foram irradiadas com um LED emitindo em $650 \mathrm{~nm}$ (Apêndice) e os espectros de absorção foram monitorados como função do tempo durante a irradiação. Foram obtidas taxas de fotodegradação dos fotossensibilizadores e rendimento quântico de produção de oxigênio singlete. 


\section{2 \\ Técnica}

Para os estudos da técnica dessa dissertação, foram utilizados conceitos descritos na literatura, principalmente em fontes como: Molecular Fluorescence (Valeur, 2001), Fundamentos da Espectroscopia de Absorção Óptica (Borissevitch et al., 2015), A Luz na Medicina Moderna (Borissevitch \& Ferreira, 2016).

\section{1.}

\section{Absorção}

Dos tipos de interação dos fótons com as moléculas, podemos considerar que a luz pode ser espalhada (mudando a direção de propagação da onda) ou absorvida (sua energia é transferida para a molécula). No caso da absorção, efeito relevante para esse trabalho, utilizamos a espectroscopia de absorção que analisa a intensidade da onda eletromagnética absorvida pelo material em função do comprimento de onda. Dado que a energia dos fótons é quantizada em pacotes de energia chamados “quantum”, a energia do fóton absorvido é dada por:

$$
E=h f=h c / \lambda
$$

onde h é a constante de Planck $h=6,63 \times 10^{-34} \mathrm{Js}$ e c é a velocidade da luz no vácuo $c=299792458 \mathrm{~m} / \mathrm{s}$ e $\lambda$ é o comprimento de onda da onda incidente. A probabilidade de ocorrer cada processo é uma propriedade específica de cada molécula. Quando a energia eletromagnética da luz é absorvida, a molécula pode passar para um estado conhecido como estado excitado. Dá-se o nome de cromóforo as moléculas que podem passar por esse processo.

Essas transições e interações interatômicas são explicadas com base na mecânica quântica onde o estado de uma molécula ou de um sistema quântico é representado por uma função de onda $\psi$ que engloba coordenadas espaciais, spins, interações com campos externos etc. É através dessa função que temos uma distribuição de probabilidade de encontrar um dado sistema em uma determinada posição, energia, spin etc. A mecânica quântica também descreve o comportamento de energia de uma molécula como um conjunto discreto de valores, chamados de 
níveis de energia. Esses níveis são determinados pelas possíveis distribuições dos elétrons em cada átomo e molécula, sendo assim, chamamos de níveis eletrônicos de energia. Cada um desses níveis eletrônicos é desdobrado em outros níveis que indicam os modos de vibração molecular, por isso são chamados de níveis vibracionais. Estes também possuem subníveis que estão relacionados com as rotações, sendo conhecidos como níveis rotacionais. A Figura 2.1 mostra um diagrama com os níveis de energia, sendo o estado de mais baixa energia, conhecido como estado fundamental $\left(\mathrm{E}_{0}\right)$ e os de energias maiores são chamados de estados excitados $\left(E_{1}\right)$.

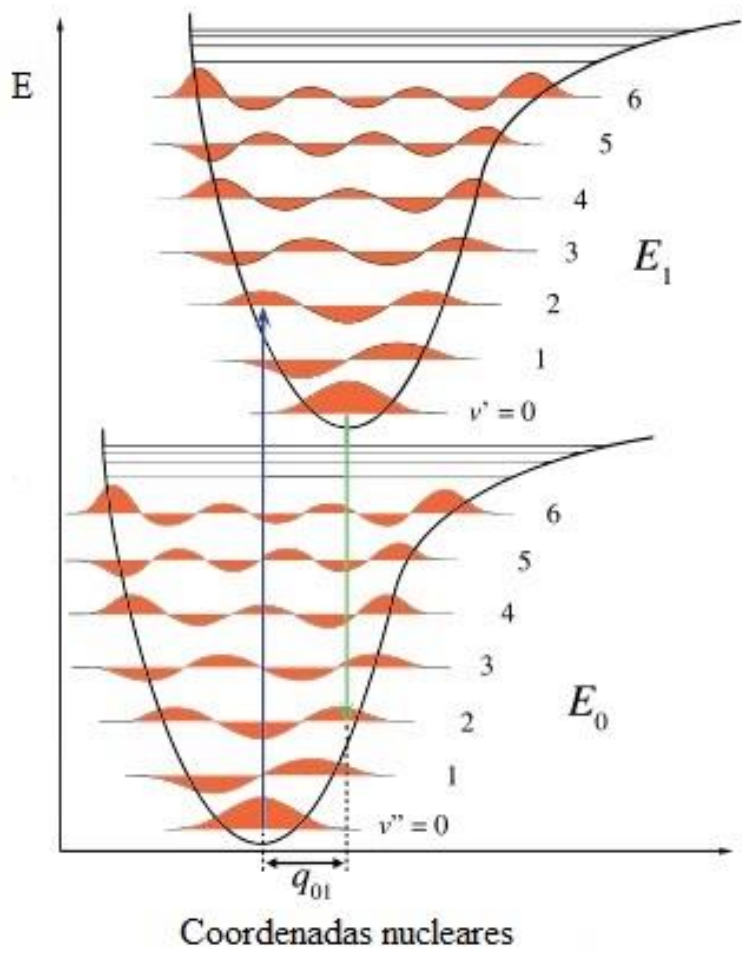

Figura 2.1. Diagrama representando as transições verticais, onde a linha azul indica absorção e a verde, emissão. $\mathrm{O}$ nível de energia $\mathrm{E}_{0}$ representa o estado eletrônico fundamental e $\mathrm{E}_{1}$, o primeiro estado eletrônico excitado. Os níveis $v$ são níveis vibracionais.

As moléculas tendem a permanecer no estado de menor energia, estado fundamental, podendo ser excitadas quando irradiadas, se essa energia da irradiação incidente for maior ou igual a diferença de energia entre os níveis.

Pela mecânica quântica também vimos que cada molécula possui orbitais eletrônicos associados a um conjunto de números chamados de números quânticos, são eles: principal, orbital e de spin. Os níveis de energia desses orbitais também estão associados a esses números. Os elétrons dessas moléculas ocupam os orbitais associados a esses números quânticos respeitando o princípio de exclusão de Pauli. 
Para o caso dos elétrons, o spin possui valores fracionados: 1/2 e -1/2. De acordo com o princípio da exclusão de Pauli, dois elétrons não podem ter os mesmos números quânticos. Consequentemente para um mesmo orbital podem existir apenas dois elétrons cujos spins são diferentes, de forma que o spin total será $\mathrm{S}=$ $\frac{1}{2}+\left(-\frac{1}{2}\right)=0$. A multiplicidade dos estados, dada por $m=2 s+1$, implica que, neste caso, $m=1$. Esse estado é chamado "singlete" e é representado por $\mathrm{S}$. Sendo $\mathrm{S}_{0}$ o estado singlete fundamental. Quando um desses elétrons passa para um orbital de maior energia e seu spin permanece inalterado, portanto mesmo $\mathrm{S}$, (e por consequência mesmo $\mathrm{m}$ ) dizemos que está no estado singlete excitado $\mathrm{S}_{\mathrm{n}}$. Quando os elétrons se encontram em orbitais diferentes, as orientações dos seus spins $S_{1} \mathrm{e}$ $S_{2}$ são independentes e três situações são possíveis para o spin total: $S_{1}=\frac{1}{2}+\frac{1}{2}=$ $1, S_{2}=\frac{1}{2}-\frac{1}{2}=0, S_{3}=-\frac{1}{2}-\frac{1}{2}=-1$. Sendo assim, temos três valores possíveis para $\mathrm{m}, m=-1,0,1$, chamado de estado "triplete" e representado pela letra $\mathrm{T}$.
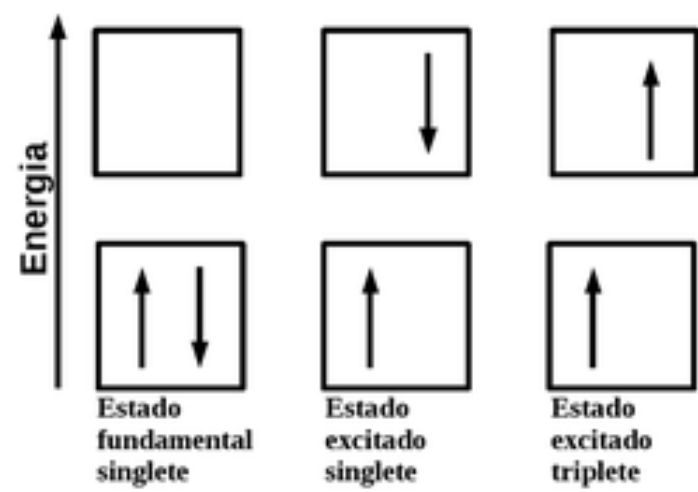

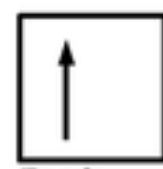

Estado excitado singlete

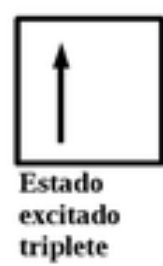

Figura 2.2. Esquema da representação dos spins nos estados singlete (fundamental e excitado) e estado excitado triplete.

A Figura 2.2 mostra o esquema da distribuição dos spins nos estados singlete e triplete. Pela regra de Hund, o estado triplete apresenta, para uma mesma configuração, energia menor que o estado singlete.

\section{2.}

\section{Lei de Beer Lambert}

Experimentalmente a eficiência da absorção da luz de um comprimento de onda $\lambda$ em um meio é caracterizado pela absorbância $A(\lambda)$ ou transmitância $T(\lambda)$ cuja relação entre eles é dada por: 


$$
A(\lambda)=\log \frac{I_{\lambda}^{0}}{I_{\lambda}}=-\log T(\lambda)
$$

onde $I_{\lambda}^{0}$ e $I_{\lambda}$ são intensidades da luz incidente e transmitida. Em alguns casos a absorbância de uma amostra segue a Lei de Beer Lambert:

$$
A(\lambda)=\log \frac{I_{\lambda}^{0}}{I_{\lambda}}=\varepsilon(\lambda) c l
$$

onde $\varepsilon(\lambda)$ é o coeficiente de absorção molar $\left(L \mathrm{~mol}^{-1} \mathrm{~cm}^{-1}\right)$, c é a concentração molar das partículas espalhadoras $\left(\mathrm{mol} \mathrm{L}^{-1}\right)$ e $l$ é o caminho óptico $\left(\mathrm{cm}^{-1}\right)$.

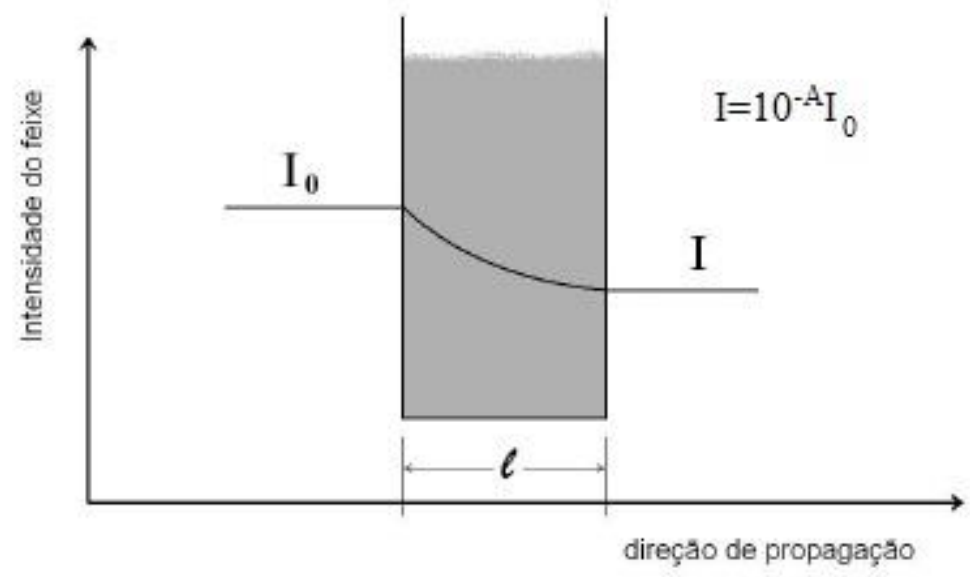

Figura 2.3. Esquema representativo da absorção da luz por uma amostra em função da distância $l$ percorrida pela luz no interior da amostra. Figura adaptada (Galo e Colombo, 2009)

Para essa dissertação, utilizamos os espectros de absorção das nossas amostras para análises de decaimento do DPBF devido a sua degradação pelo oxigênio singlete produzido pelos fotossensibilizadores.

\section{3.}

\section{Absorção e processos de desexcitação}

Quando o fotossensibilizador absorve um fóton, dependendo da energia, a molécula pode passar do estado eletrônico fundamental a um estado excitado. Para minimizar a energia, o elétron no nível excitado tende a se rearranjar e retornar ao seu estado fundamental. Essa transição pode ser feita de através de alguns processos esquematizados na Figura 2.4 (Valeur, 2001). 


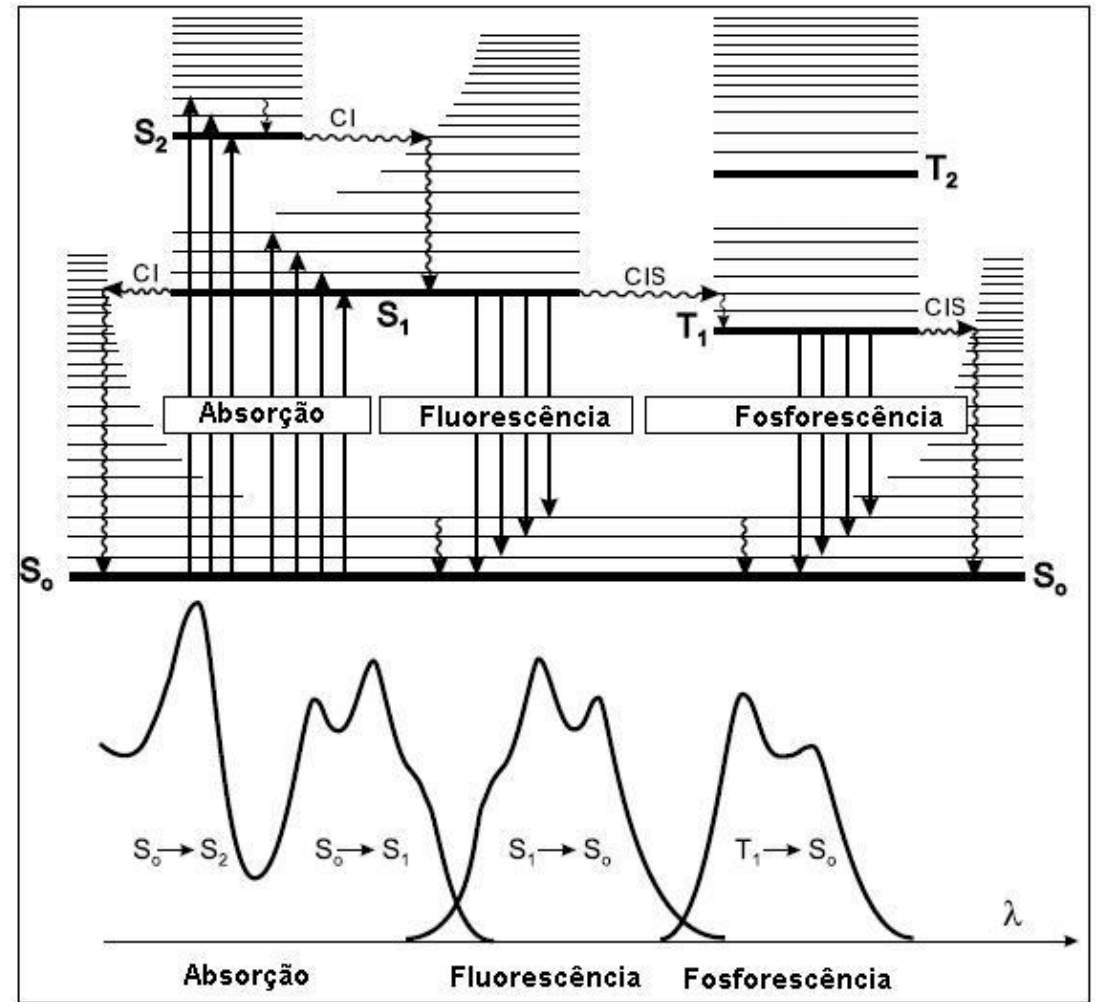

Figura 2.4. Diagrama de Jablonski e associação das posições relativas dos espectros de absorção, fluorescência e fosforescência.

A Figura 2.4 mostra a molécula no nível $\mathrm{S}_{0}$ que ao absorver um fóton com energia suficiente, passa do estado $S_{0}$ fundamental para um estado $S_{n}$ excitado e a partir desse nível pode ir para o estado $S_{1}$ através da relaxação vibracional. Esse processo é conhecido como conversão interna $(\mathrm{CI})$ e é descrito pela transição não radiativa entre dois estados eletrônicos de mesma multiplicidade de spin. A energia excedente entre os estados $S_{1}$ e $S_{0}$ pode ser liberada na forma de luz pela emissão de fluorescência. Também pode ocorrer a transição entre o estado $S_{1}$ e o estado $T_{1}$ através do cruzamento intersistemas (CIS) que é uma transição não radiativa entre dois níveis vibracionais com estados eletrônicos de diferentes multiplicidades de spin. O ICS é menos provável e depende dos estados singlete e triplete dos materiais envolvidos.

Para os fotossensibilizadores que funcionam através do mecanismo tipo II, a absorção gera estados tripletes excitados, através de CIS. Em consequência, pode voltar ao estado fundamental transferindo energia a moléculas de oxigênio, cujo estado fundamental é triplete, produzindo oxigênio singlete. A produção de ${ }^{1} \mathrm{O}_{2}$ é medida indiretamente pela degradação do DPBF. 


\section{3 \\ Materiais e métodos}

\section{1.}

\section{Materiais utilizados}

Nanopartículas de ouro (AuNPs): produzidas pelo doutorando Tahir, sob orientação professor Tommaso del Rosso, ambos do Laboratório de Síntese e Caracterização a Laser de Nanomateriais (NanoLaser) do Departamento de Física da PUC-Rio, através do processo de ablação a laser (Figura 3.1) de uma superfície de ouro puro em água utilizando o laser verde $532 \mathrm{~nm}$ (Del Rosso, et al. 2018). O ouro utilizado para ablação foi adquirido da companhia Kurt J. Lesker com pureza maior que $99 \%$.
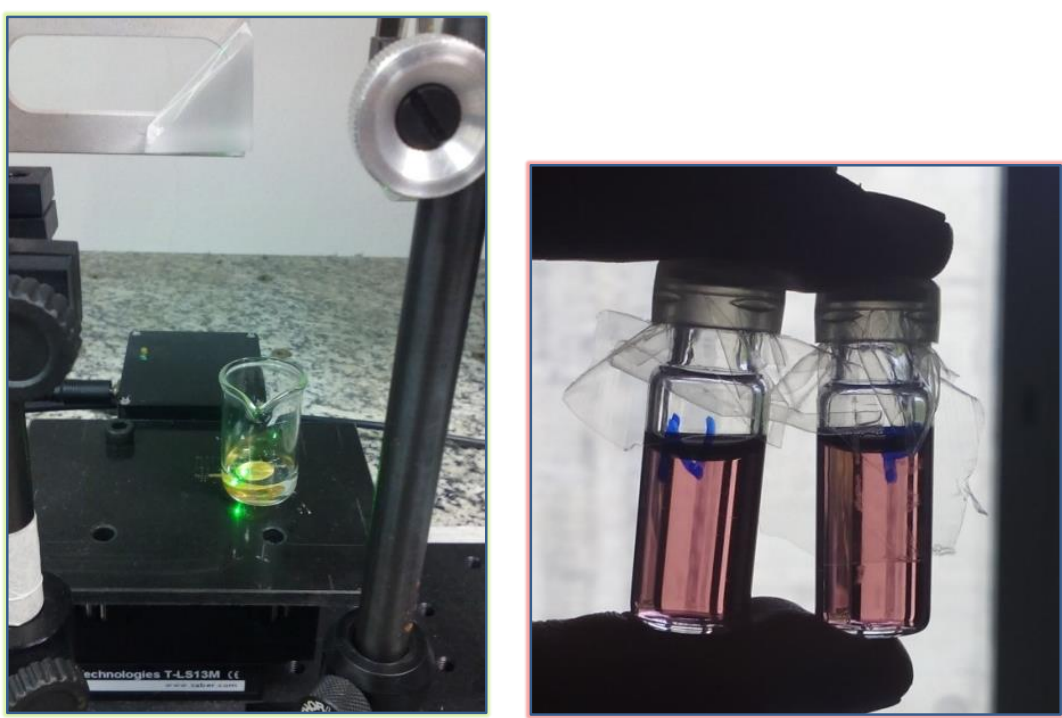

Figura 3.1: Ouro posicionado durante a ablação a laser (esquerda) e amostras de nanopartículas não aglomeradas em água (direita).

A citotoxicidade das nanopartículas de ouro produzidas, analisada em fibroblastos humanos para diferentes concentrações de nanopartículas com e sem acréscimo do copolímero Pluronic F-127, mostrou que o material não apresenta toxicidade na ausência dos fotossensibilizantes e de excitação por luz (Del Rosso, et al. 2018). 
O copolímero Pluronic F-127 foi adquirido do fabricante Sigma-Aldrich.

Dos fotossensibilizadores, a clorina e6 foi adquirida do fornecedor Frontier Scientific com pureza maior que $95 \%$ e o azul de metileno, do fabricante SigmaAldrich com pureza $97 \%$.

$\varepsilon_{\text {Ce6 } 402}=9,5 \times 10^{4} \mathrm{M}^{-1} \mathrm{~cm}^{-1} \quad \varepsilon_{M B 663}=4,7 \times 10^{4} \mathrm{M}^{-1} \mathrm{~cm}^{-1}$

Utilizado com sonda para detecção do oxigênio singlete, 1,3difenilisobenzofurano (DPBF) foi adquirido do fabricante Sigma-Aldrich com pureza $97 \%$. $\varepsilon_{D P B F}=2,3 \times 10^{4} \mathrm{M}^{-1} \mathrm{~cm}^{-1}$

\section{2.}

\section{Preparação das amostras}

As nanopartículas de ouro foram obtidas pela a técnica de ablação em água (Amendola and Meneghetti, 2013) pelo doutorando Tahir e Prof. Tommaso Del Rosso (Del Rosso, et al. 2018).

Os procedimentos para recobrimento das nanopartículas foram realizados no Laboratório de Biofísica e Tratamento de Materiais do Departamento de Física da PUC-Rio, seguindo o procedimento padrão:

Dia 1: Após a produção das nanopartículas, via ablação a laser em água, dividimos o volume total de nanopartículas de ouro em duas partes:

- Para produção das nanopartículas aglomeradas $\left(\mathrm{AuNP}_{\mathrm{a}}\right)$.

Acrescenta-se cloreto de sódio $(\mathrm{NaCl})$ à suspensão de nanopartículas para estimular a aglomeraração, efeito que pode ser observado pelo espectro de absorção e pela mudança de cor da suspensão. Ao atingir o grau de aglomeração desejado, coloca-se o polímero Pluronic F-127 para estabilizar as nanopartículas e deixa-se interagir por uma noite.

- $\quad$ Para produção das nanopartículas não aglomeradas (AuNPs). Adiciona-se apenas o polímero Pluronic F-127 para estabilizar as nanopartículas e deixase interagir por uma noite.

Dia 2: Acrescentamos o fotossensibilizador (Ce6 ou MB) e aguardamos por uma noite.

Dia 3: Preparamos a solução estoque de DPBF 5 mM em etanol. 
Fizemos a medida de absorção das amostras contendo as nanopartículas e Pluronic F-127 ainda sem a sonda DPBF.

Acrescentamos a sonda DPBF e medimos sua degradação, causada pela produção de oxigênio singlete ao irradiarmos as amostras com o LED de $650 \mathrm{~nm}$ (Apêndice 1).

\section{3. Procedimento Experimental}

Os experimentos de espectrofotometria foram realizados no Laboratório de Espectroscopia de Biomoléculas no Departamento de Física da PUC-Rio onde fizemos medidas do espectro de absorção das nossas amostras utilizando o espectrofotômetro UV-Vis da Perkin Elmer, modelo Lambda 950 (Figura 3.2).

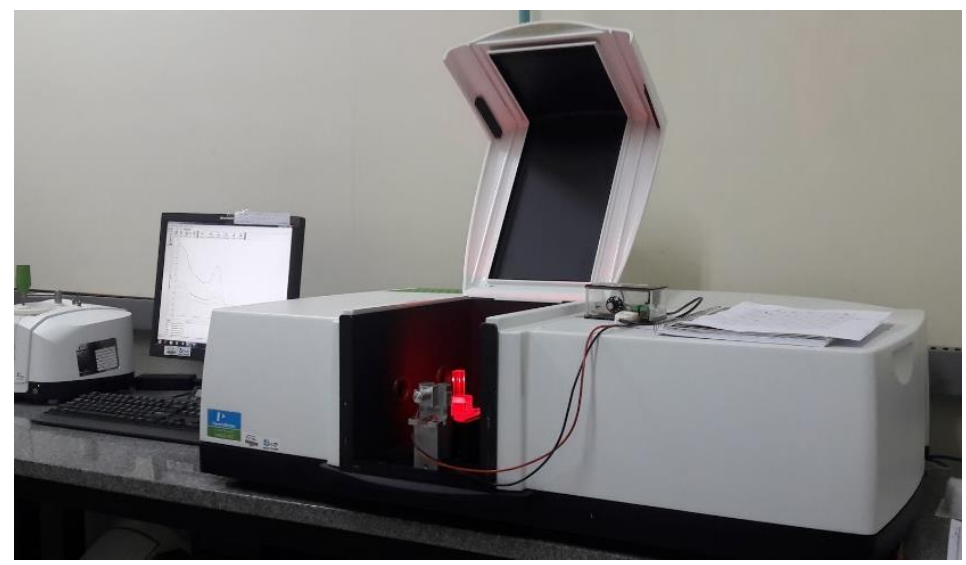

Figura 3.2 Equipamento espectrofotômetro UV/VIS Perkin Elmer modelo Lambda 950

Através do decaimento da absorção da molécula de DPBF podemos calcular a fotodegradação do material e assim comparar as produções de oxigênio singlete durante a exposição à luz. Essa irradiação foi feita utilizando o LED vermelho profundo (Apêndice 1) com emissão centrada no comprimento de onda $650 \mathrm{~nm}$ (Figura 3.3) irradiância de aproximadamente $20 \mathrm{~mW} / \mathrm{cm}^{2}$ a $5 \mathrm{~cm}$ do LED.

A Figura 3.3 mostra a região de emissão do LED vermelho, centrada em $658 \mathrm{~nm}$, utilizado para irradiar as amostras que medimos. Esse LED foi adicionado a um circuito (Apêndice 1) no qual podemos controlar a intensidade da luz emitida pelo LED que estimula a produção do oxigênio singlete produzidos pelos fotossensibilizadores. 


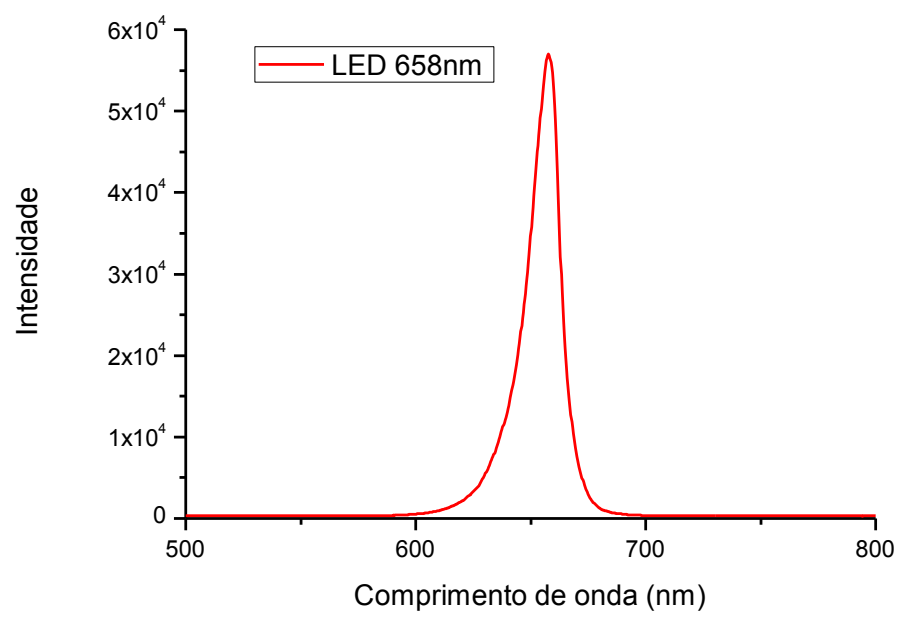

Figura 3.3. Espectro do LED utilizado para irradiar as amostras.

Para impedir que a luz do LED sature o detector do espectrofotômetro, utilizamos duas alternativas:

1) Usar filtro passa banda $\mathrm{C} 3 \mathrm{C} 22$, produzido na Universidade de $\mathrm{Kiev}$, que transmite na região de comprimentos de onda entre 375 nm e 525 nm (Figura 3.4), região favorável para acompanhar o decaimento da sonda DPBF.

2) Usar o interruptor acoplado ao circuito controlador do LED para apagar a luz durante das medidas. Essa alternativa é útil para vermos regiões que o filtro bloqueia o espectro. Em contrapartida, não uso do filtro aumenta o tempo de medida, pois a irradiação só poderá ser feita entre os escaneamentos da amostra.

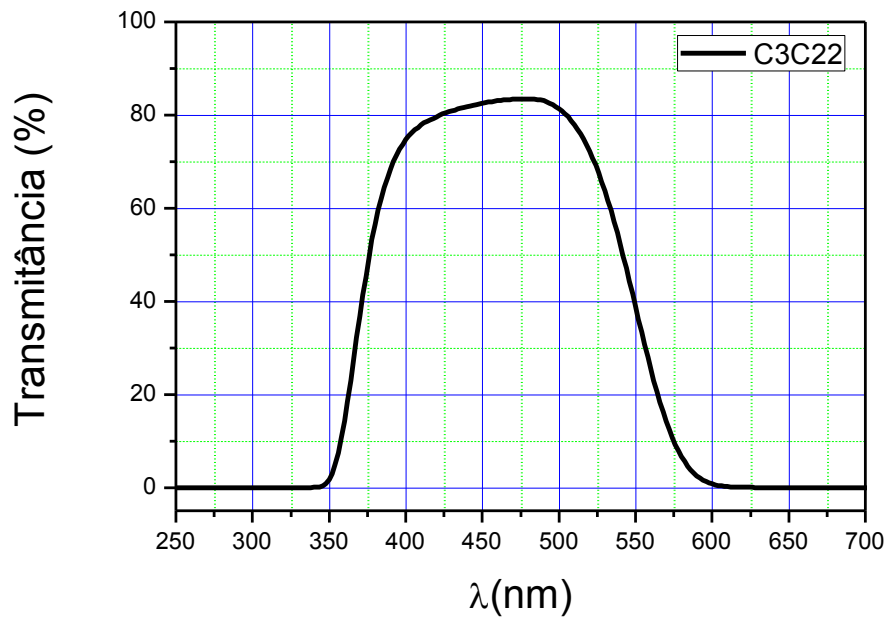

Figura 3.4: Espectro de transmitância do filtro C3C22 feito pelo doutorando Rian Aderne sob orientação do professor Marco Cremona 

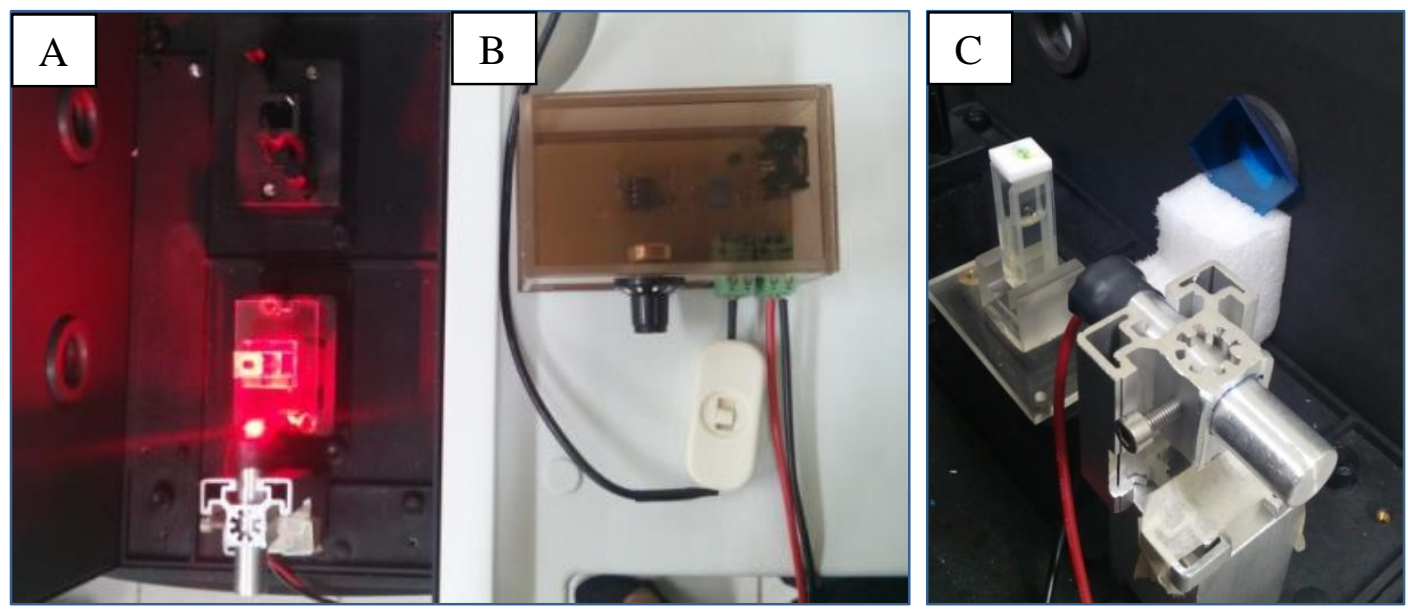

Figura 3.5: Esquema de montagem experimental dentro e fora do compartimento de amostras do espectrofotômetro. A) o LED posicionado de frente para a cubeta; B) o circuito controlado do LED do lado de fora e C) a montagem com o filtro.

A Figura 3.5 mostra (A) o LED vermelho aceso dentro do espectrofotômetro posicionado a $3 \mathrm{~cm}$ do centro da cubeta onde medimos as amostras; (B) circuito montado para controle da intensidade da luz do LED posicionado fora do espectrofotômetro e (C) a imagem de dentro do compartimento de amostras do espectrômetro do espectrofotômetro mostrando o suporte do LED (apagado) de frente para a cubeta e filtro azul C3C22 na entrada da luz para o detector. 


\section{4 \\ Resultados e Discussões}

Neste capítulo serão apresentados e discutidos os resultados dos estudos da produção de oxigênio singlete pelos fotossensibilizadores clorina e6 e azul de metileno e da fotodegradação dos mesmos durante a irradiação pelo LED de $650 \mathrm{~nm}$ (Figura 3.3). A produção de oxigênio singlete em presença e ausência de nanopartículas (AuNPs) é detectada através da taxa de decaimento da absorção do DPBF, utilizado como sonda. A taxa de fotodegradação (fotobranqueamento) é obtida a partir do espectro de absorção do próprio fotossensibilizador.

A Figura 4.1 (a) mostra o espectro de absorção do fotossensibilizador clorina e6 em tampão. Observa-se um pico intenso de absorção em $402 \mathrm{~nm}$ (banda de Soret), um bem menos intenso em $504 \mathrm{~nm}$ e um com intensidade intermediária em $654 \mathrm{~nm}$, já na janela fototerapêutica. Escolhemos a luz de excitação em 650 nm, correspondendo a esse último pico do fotossensibilizador por ser na faixa de luz compatível com absorção por tecido humano.

A Figura 4.1 (b) mostra o espectro de absorção do fotossensibilizador azul de metileno. Seu pico mais intenso de absorção localiza-se em $665 \mathrm{~nm}$, mas observase que em $650 \mathrm{~nm}$ a absorção é também bastante intensa. Portanto a mesma luz de excitação pode ser utilizada em ambos fotossensibilizantes escolhidos.

O espectro de absorção de DPBF em água é mostrado na Figura. 4.2. Observa-se um pico em $420 \mathrm{~nm}$. O DPBF é extremamente sensível à luz e sofre fotodegradação mesmo sob luz ambiente. Observa-se, no entanto, que sua absorção é praticamente nula em $650 \mathrm{~nm}$. A iluminação nesse comprimento de onda, portanto, praticamente não produz fotodegradação e modificações no seu espectro são devidas à reação com oxigênio singlete produzido pelo fotossensibilizador. 

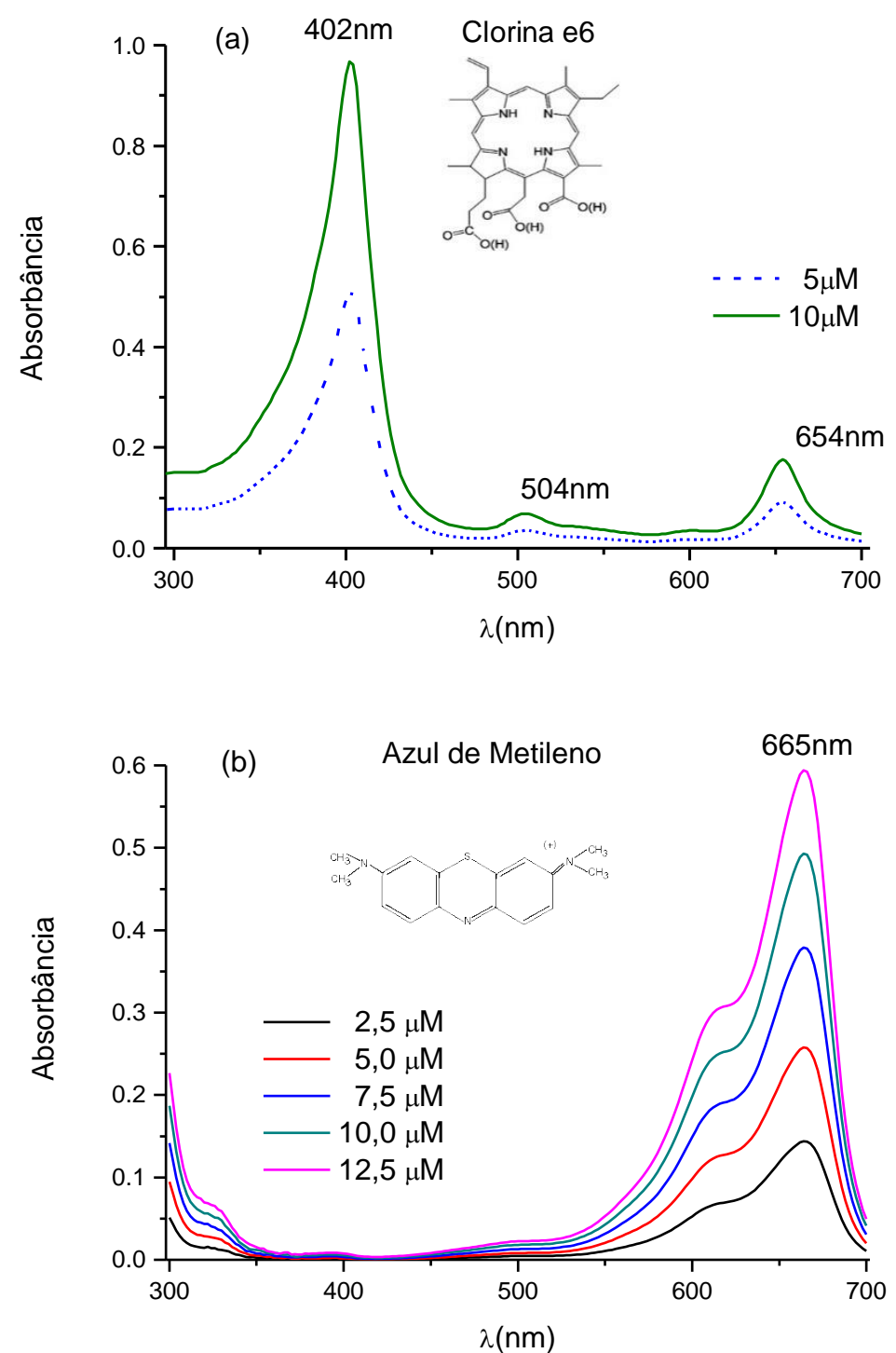

Figura 4.1 (a) Estrutura molecular da clorina e6 e seu espectro de absorção óptica. (b) Estrutura molecular do azul de metileno e seu espectro de absorção óptica. 


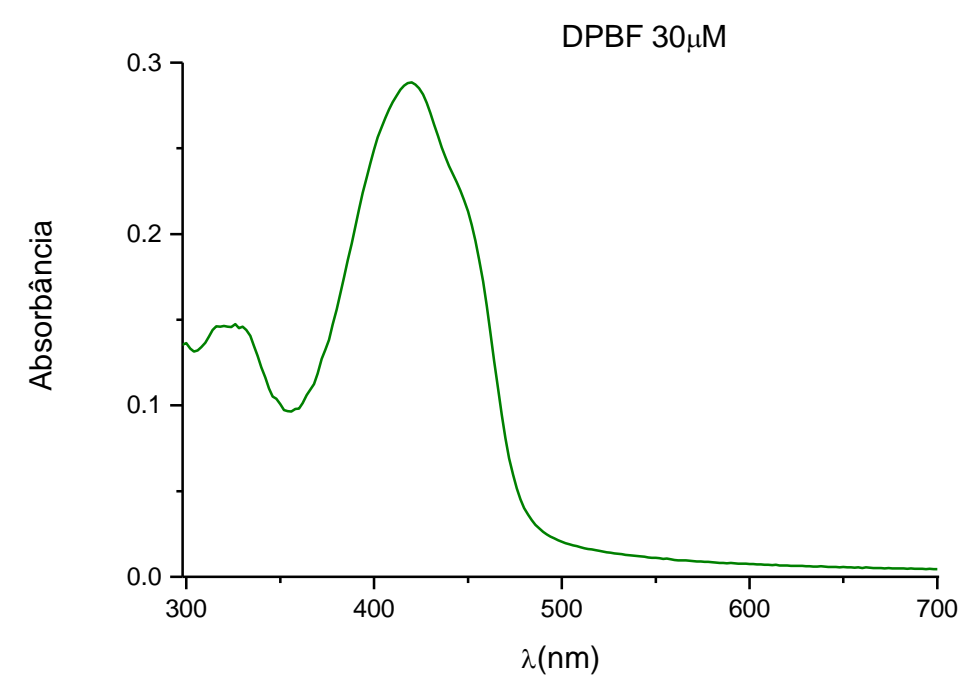

Figura 4.2. Espectro de absorção de $30 \mu \mathrm{M}$ DPBF em água.

O uso das nanopartículas de ouro associadas aos fotossensibilizadores para terapia fotodinâmica visa, além do uso de diagnóstico e terapia associados (teranóstico), a amplificação da excitação devido ao efeito de ressonância plasmônica, característico das nanopartículas. As nanopartículas de ouro não aglomeradas produzidas pelo processo de ablação, possuem sua banda de absorção na região de comprimento de onda $524 \mathrm{~nm}$ (Figura 4.3). Com o intuito de usar essa amplificação do sinal da excitação na região de absorção do fotossensibilizador de mesmo comprimento de onda do LED, precisamos de nanopartículas que ressoassem na mesma região, $650 \mathrm{~nm}$. Para obter esse efeito, fizemos medidas também com nanopartículas aglomeradas, que apresentam banda plasmônica alargada e deslocada para o vermelho que engloba o comprimento de onda $650 \mathrm{~nm}$. A aglomeração foi induzida por adição de $100 \mu \mathrm{L}$ de $\mathrm{NaCl} 5 \mathrm{M}$, por mL de amostra.

Como queremos verificar o efeito de nanopartículas de ouro na produção de oxigênio singlete pelo fotossensibilizador, é importante tratar a superfície da AuNP com um composto que deixe a nanopartícula estável em condições fisiológicas e que tenha afinidade pelo fotossensibilizador. Foi verificado que o copolímero tribloco Pluronic F-127 é capaz de estabilizar as nanopartículas em condições fisiológicas (pH 7,4 e força iônica da ordem de 0,15 M) (Del Rosso et al, 2018).

Além disso as moléculas de PF-127, sendo anfifílicas, envolvem as AuNPs com uma camada capaz de solubilizar melhor tanto o fotossensibilizador como o 
sensor de ${ }^{1} \mathrm{O}_{2}$ (DPBF). Assim sendo, no nosso estudo escolhemos tratar as AuNPs com PF-127.

A Figura 4.4 mostra os espectros de extinção de nanopartículas de ouro não aglomeradas $(\mathrm{AuNP})$ e aglomeradas $\left(\mathrm{AuNP}_{\mathrm{a}}\right)$ bem como a foto das nanopartículas utilizadas.

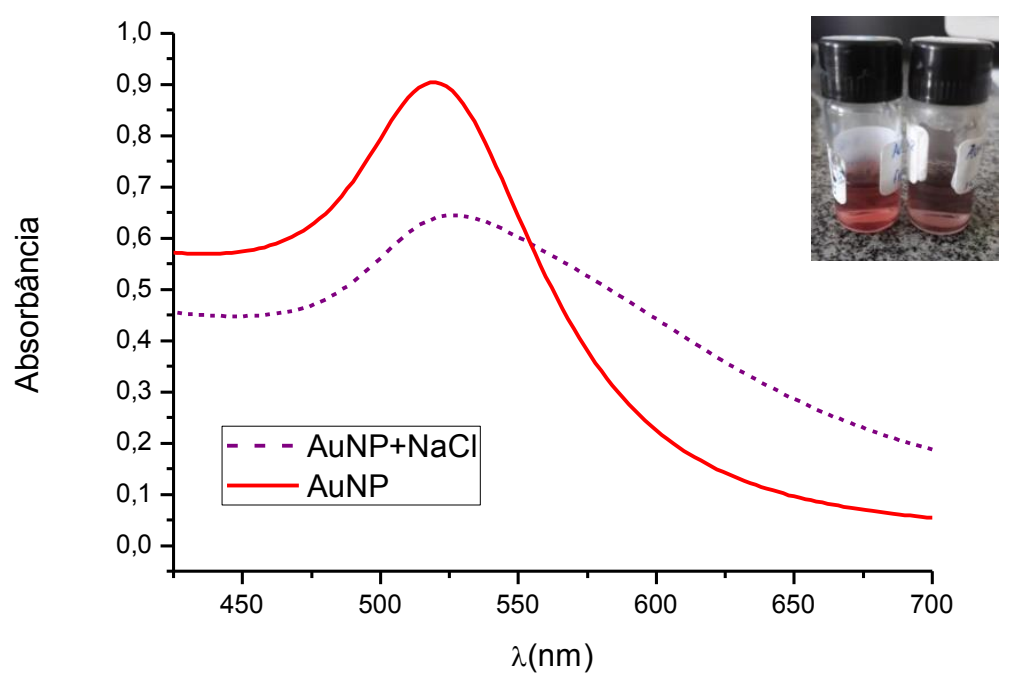

Figura 4.3. Espectros de extinção das nanopartículas aglomeradas $(\mathrm{AuNP}+\mathrm{NaCl})$ e não aglomeradas (AuNP) logo após a síntese, com adição de Pluronic F-127.

Podemos observar que o espectro em linha contínua (vermelha), das partículas não aglomeradas (AuNP), apresenta o pico de ressonância plasmônica na região de $524 \mathrm{~nm}$. Já a linha tracejada (roxa), espectro das nanopartículas aglomeradas $\left(\mathrm{AuNP}_{\mathrm{ag}}\right)$ apresenta a banda plasmônica alargada, na região entre $520 \mathrm{~nm}$ e $660 \mathrm{~nm}$, com uma diminuição do pico e um deslocamento para a região do vermelho. Tal efeito causado pela aglomeração das nanopartículas é de grande importância na nossa investigação, visto que nossos fotossensibilizadores absorvem na região do vermelho $(654 \mathrm{~nm}$ para a clorina e6 e $609 \mathrm{~nm}$ e $668 \mathrm{~nm}$ para o azul de metileno). Devido ao efeito de ressonância de plásmons de superfície localizados (LSPR), as nanopartículas, quando irradiadas em comprimentos de onda na banda plasmônica ( $650 \mathrm{~nm}$ para partículas aglomeradas), amplificam o campo eletromagnético na sua superfície, sendo assim esperado um aumento do efeito sobre os fotossensibilizadores, que por sua vez produziriam mais oxigênio singlete degradando com maior eficiência a sonda DPBF. No entanto, é esperado que esse 
efeito seja muito dependente da distância do fotossensibilizador à superfície da nanopartícula.

Nas próximas seções descrevemos os resultados da produção de ${ }^{1} \mathrm{O}_{2}$ pelos fotossensibilizadores em presença e ausência de AuNPs.

\section{1.}

\section{Influência de AuNPs na produção de ${ }^{1} \mathrm{O}_{2}$ por Clorina e6}

Nesse estudo nanopartículas de uma mesma produção, separadas em duas partes, sendo uma submetida a aglomeração com $\mathrm{NaCl}$, e a outra mantida sem aglomeração, foram colocadas em tampão fosfato pH 7,4, $10 \mathrm{mM}$ e estabilizadas com Pluronic F-127. Em seguida, clorina e6 em duas diferentes concentrações (1,0 $\mu \mathrm{M}$ e $1,5 \mu \mathrm{M})$ foi adicionada às amostras.

Utilizando a cubeta de $1 \mathrm{ml}$ e caminho óptico $1 \mathrm{~cm}$ obtivemos os espectros de absorção UV-Vis a cada 1 min de irradiação. Para essas medidas utilizamos o filtro de cor azul C3C22, que absorve a luz vermelha, para que não fosse necessário desligar a luz do LED durante a tomada de dados.

Os espectros de absorção UV-Vis da sonda DPBF na presença apenas do fotossensibilizador clorina e6 aparecem nos gráficos das Figuras 4.4 a e 4.4 b. A região acima de $550 \mathrm{~nm}$ não é possível ser vista nos espectros devido ao filtro utilizado nessa série de medidas. Os espectros mostram o decaimento da absorbância do DPBF causado pelo oxigênio singlete produzido pela clorina e6 irradiada, medida utilizada como referência para análise da interação sonda fotossensibilizador na ausência das nanopartículas. 

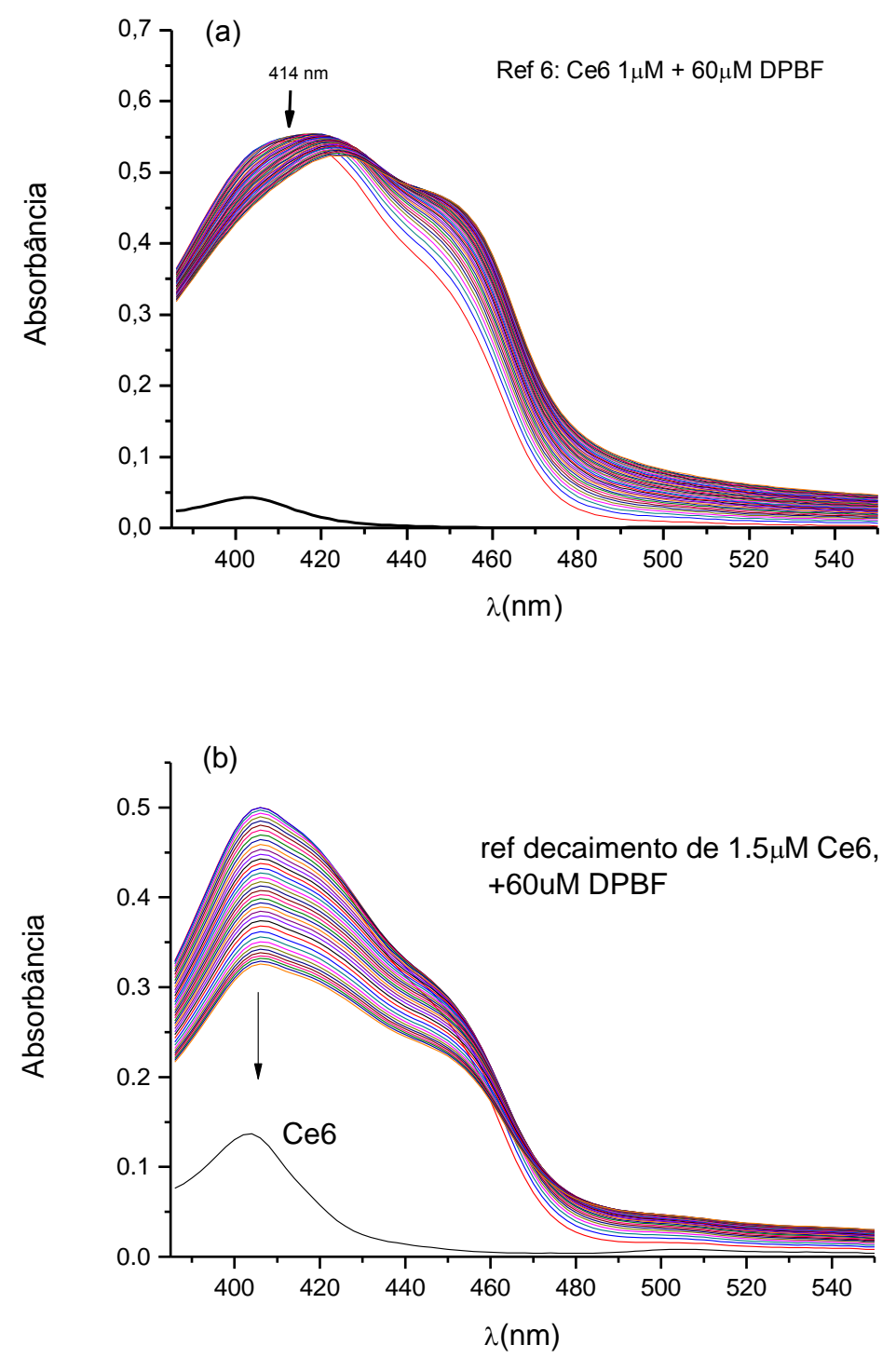

Figura 4.4. (a) Espectros de absorção da sonda DPBF na presença de $1 \mu \mathrm{M}$ de clorina e6 em tampão fosfato. (b) b Espectro de absorção da sonda DPBF na presença de 1,5 $\mu \mathrm{M}$ de clorina e6 em tampão fosfato.

Como podemos observar, o decaimento da sonda DPBF acelera com a quantidade de fotossensibilizador acrescentado, o que reforça que o decaimento depende da produção de oxigênio singlete gerado pelo fotossensibilizador.

Seguindo o mesmo padrão de medidas, fizemos amostras com as nanopartículas não aglomeradas (AuNP) após uma noite na presença do polímero PF-127 e a noite seguinte sob adição do fotossensibilizador clorina e6 ao conjunto AuNP -polímero. As Figuras 4.5 a e 4.5 b mostram os espectros de absorção do 
decaimento do DPBF sob efeito das nanopartículas não aglomeradas com diferentes

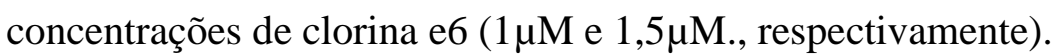
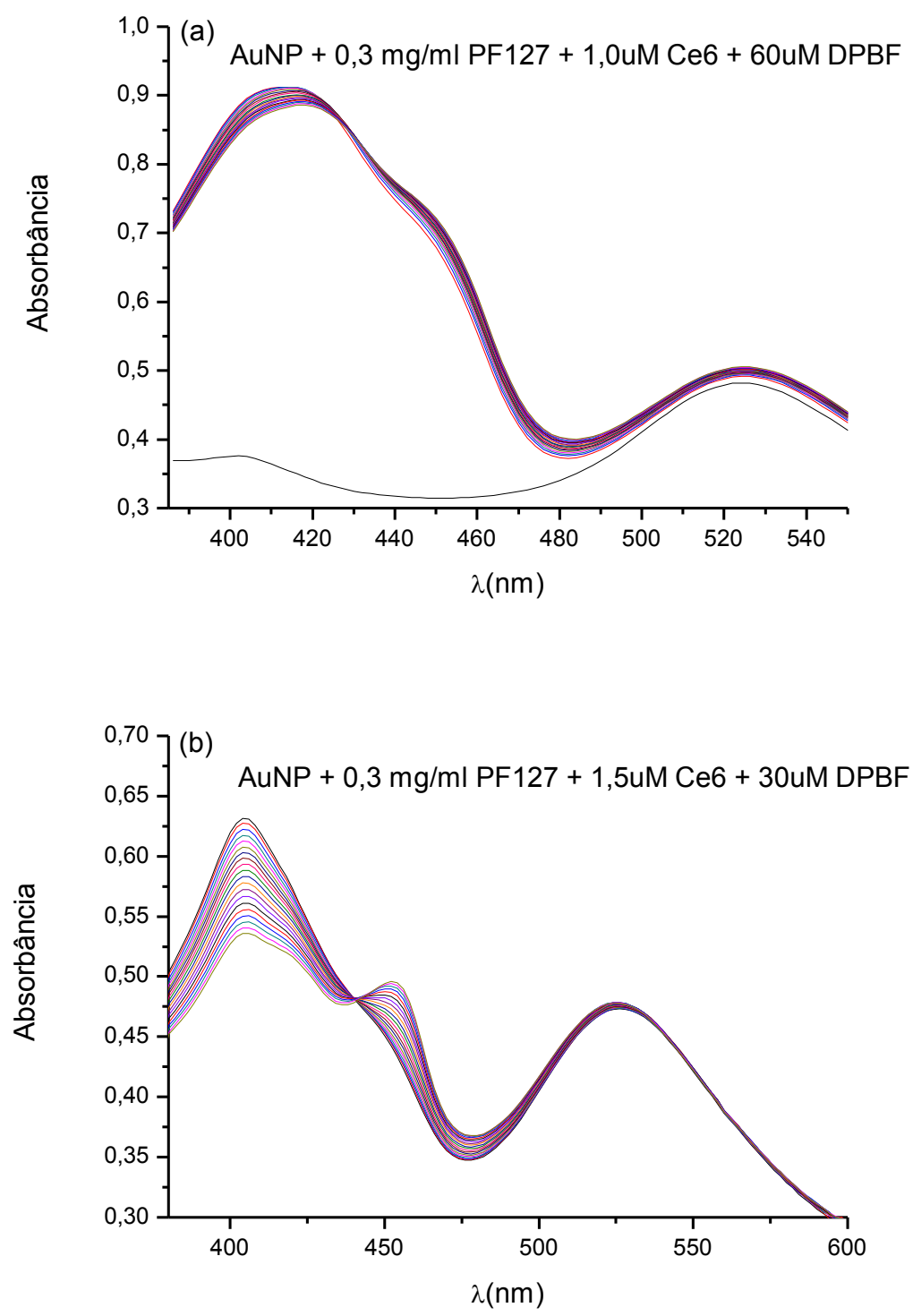

Figura 4.5. Espectros de absorção da sonda DPBF na presença de $1 \mu \mathrm{M}$ (a) e 1,5 $\mu \mathrm{M}$ (b) de clorina e6 em tampão fosfato com nanopartículas de ouro não aglomeradas estabilizadas com Pluronic F- 127

Podemos observar o decaimento do pico do DBPF em $418 \mathrm{~nm}$, o pico referente a clorina e6 em $402 \mathrm{~nm}$ e o pico das nanopartículas em $524 \mathrm{~nm}$ e um comportamento anômalo em $450 \mathrm{~nm}$ similar ao pico de emissão da sonda DPBF.

Seguindo a sequência de medidas, fizemos o mesmo estudo para as nanopartículas que sofreram aglomeração com $\mathrm{NaCl}$ e foram estabilizadas com pluronic F-127 (AuNP ag). Deixamos sob efeito apenas do polímero por uma noite, 
acrescentamos o fotossensibilizador clorina e6, aguardamos mais uma noite para no dia seguinte fazermos as medidas de decaimento da sonda.

A Figura 4.6 mostra o decaimento da sonda DPBF sob influência da irradiação com LED de $650 \mathrm{~nm}$ e do fotossensibilizante Ce6 em duas concentrações diferentes em amostras com nanopartículas aglomeradas recobertas com PF-127.
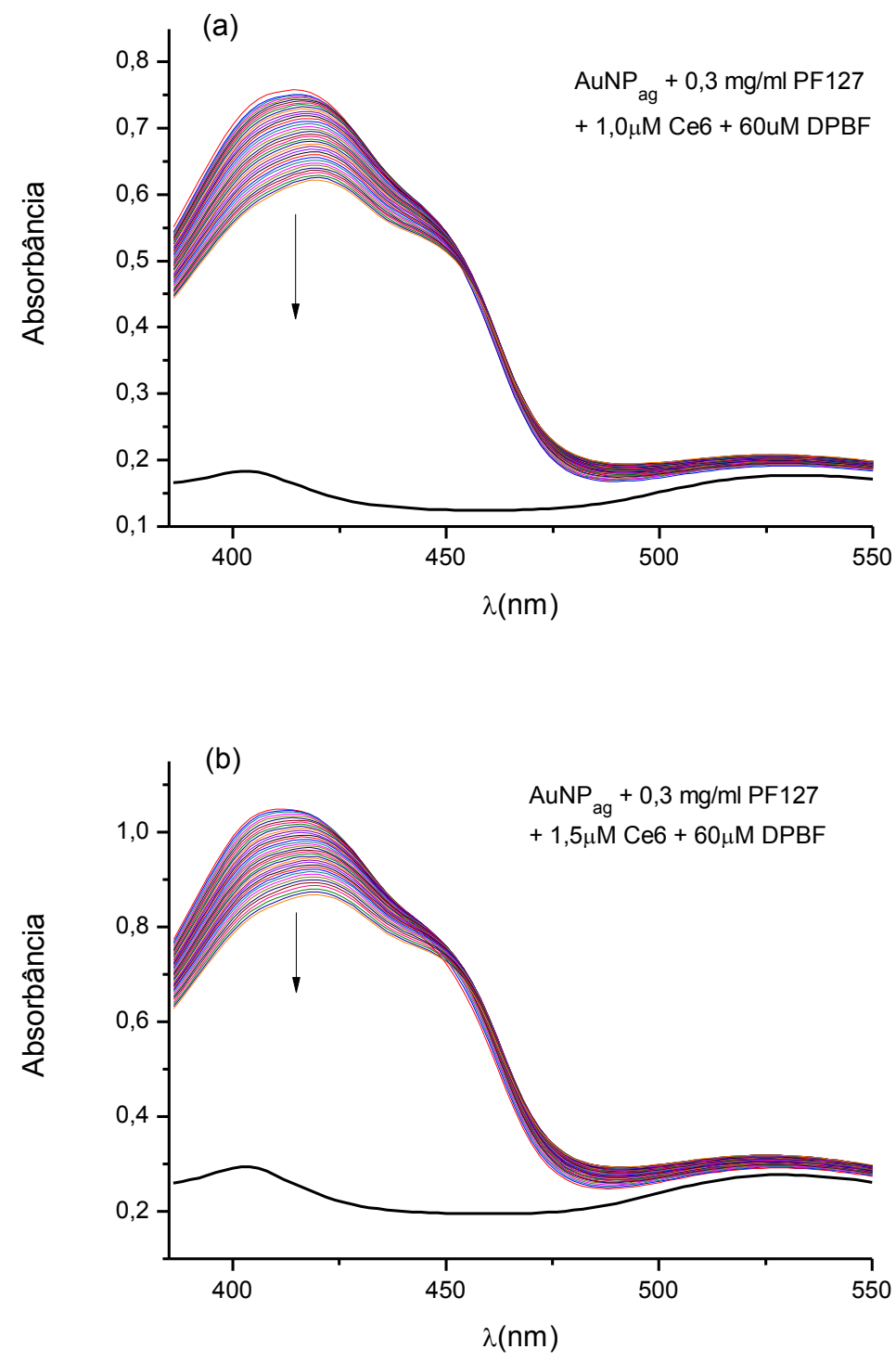

Figura 4.6. Espectros de absorção da sonda DPBF em (a) clorina e6 1,0 $\mu \mathrm{M}$ e (b) clorina e6 $1,5 \mu \mathrm{M}$ ambas em nanopartículas de ouro aglomeradas estabilizadas com PF-127 em tampão.

Para melhor comparação, fizemos gráficos dos decaimentos de DPBF em função do tempo de irradiação das amostras. Consideramos a absorção em $418 \mathrm{~nm}$ das medidas no pico da sonda DPBF (Figura 4.7). 


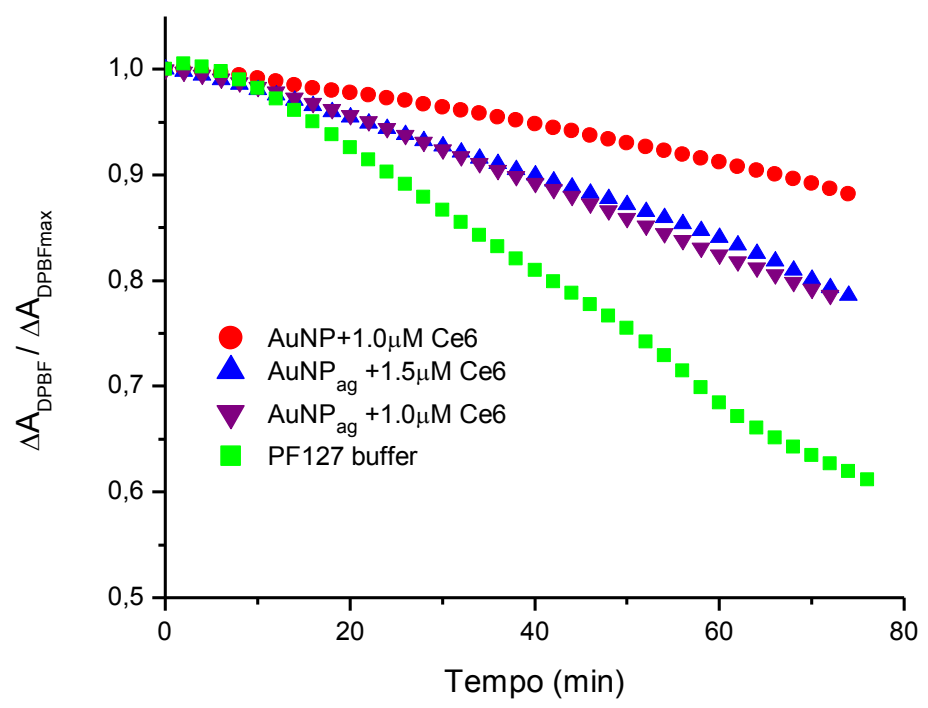

Figura 4.7: Decaimento da absorção do DPBF em amostras de nanopartículas aglomeradas $\left(\right.$ AuNP $\left._{\mathrm{ag}}\right)$ e não aglomeradas (AuNP) com diferenctes concentrações de clorina e6 $(1,0 \mu \mathrm{M}$ e $1,5 \mu \mathrm{M})$ em função do tempo de irradiação

onde o $\triangle \mathrm{A}_{\text {DPBFmax }}$ é a variação da absorção (em relação a absorbância inicial $\mathrm{A}_{0}$, logo após a adição do DPBF) e $\triangle \mathrm{A}_{\mathrm{DPBF}}$ é a mesma variação em um tempo posterior. Podemos observar que as nanopartículas não aglomeradas (AuNP) com 1,0 $\mu \mathrm{M} \mathrm{Ce} 6$ produzem menos radicais livres que degradam o DPBF. Quando usamos as nanopartículas aglomeradas $\left(\mathrm{AuNP}_{\mathrm{ag}}\right) \operatorname{com} 1,0 \mu \mathrm{M}$ ou $1,5 \mu \mathrm{M}$ Ce6 o decaimento é acelerado. A degradação pareceu ainda mais eficiente para a solução em presença de PF-127, sem as nanopartículas.

Para analisar mais precisamente a produção de ${ }^{1} \mathrm{O}_{2}$, normalizamos o decaimento pela concentração da clorina e6, tomando o $\Delta \mathrm{A}=\left(\mathrm{A}_{\mathrm{o}}-\mathrm{A}\right)$, sendo $\mathrm{A}_{\mathrm{o}}$ a absorção logo após a adição do DPBF e A, num determinado tempo. O $\Delta \mathrm{A}$ é proporcional ao consumo de DPBF e, portanto, à produção de ${ }^{1} \mathrm{O}_{2}$, se considerarmos que a concentração de DPBF é suficientemente alta, para que cada ${ }^{1} \mathrm{O}_{2}$ produzido reaja com DPBF. De acordo com essa hipótese, a Figura 4.8, que apresenta a variação de absorbância em função do tempo, mostra também a produção de ${ }^{1} \mathrm{O}_{2}$.

Vemos (Fig. 4.8) que, utilizando as nanopartículas não aglomeradas, a taxa de decaimento foi bem semelhante à da amostra sem nanopartículas e ambas as amostras mostram produção mais lenta de ${ }^{1} \mathrm{O}_{2}$. Já as nanopartículas aglomeradas, 
para as duas concentrações Ce6, mostraram uma eficiência maior ao indicarem uma maior produção de oxigênio singlete para um mesmo intervalo de tempo.

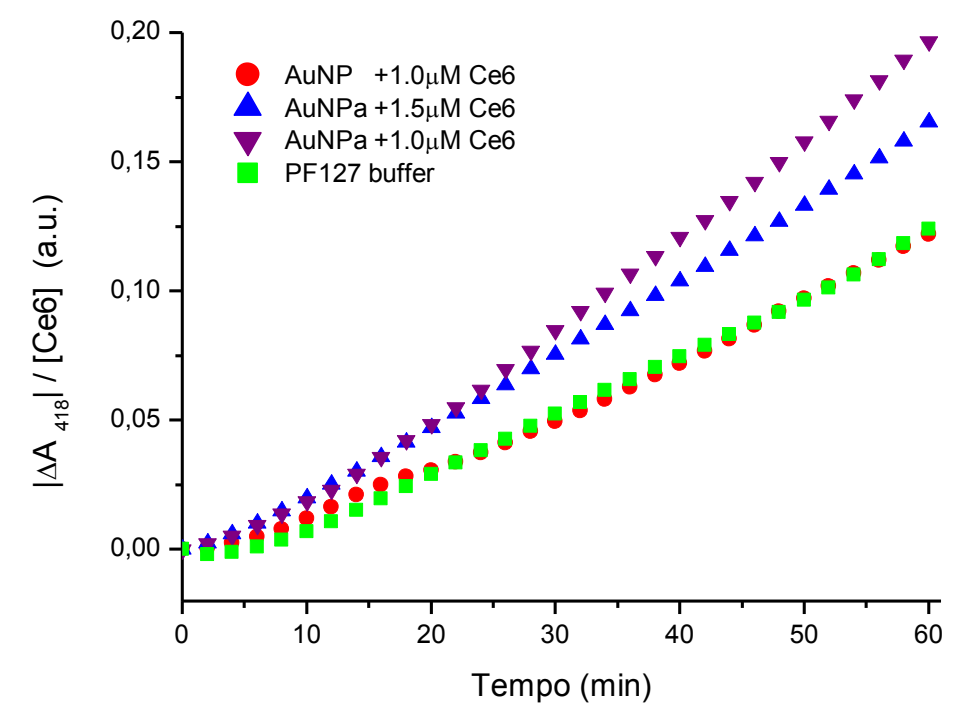

Figura 4.8. ( $\left(\mathrm{A}_{0}-\mathrm{A}\right)$ em $418 \mathrm{~nm}$ normalizado pela concentração de Ce6 como função do tempo. [Ce6] foi obtida da absorbância da clorina em $402 \mathrm{~nm}$. 


\section{2.}

\section{Influência de AuNPs na produção de ${ }^{1} \mathrm{O}_{2}$ por Azul de Metileno}

Nesse estudo colocamos em tampão fosfato (PB) $10 \mathrm{mM}, \mathrm{pH} 7,4$, nanopartículas de uma mesma produção, na qual parte aglomeramos com $\mathrm{NaCl}$, e a outra parte mantivemos sem aglomeração. Estabilizamos ambos os tipos com Pluronic F-127 e adicionamos concentração de $2 \mu \mathrm{M}$ de azul de metileno. Utilizando cubeta de $1 \mathrm{ml}$ e caminho óptico $1 \mathrm{~cm}$, obtivemos os espectros de absorção UV-Vis de amostras irradiadas durante intervalos de 1 min entre as medidas no espectrofotômetro.

Essas medidas foram realizadas sem o uso do filtro de cor azul $\mathrm{C} 3 \mathrm{C} 22$ (Figura 3.4) para que pudéssemos ver a região de absorção do azul de metileno. Para isso as irradiações foram feitas ligando o LED nos intervalos entre as medidas e desligando durante as medidas para evitar saturação do detector.

A Figura 4.1(b) mostra a absorção do azul de metileno. Como podemos perceber, o pico de absorção do fotossensibilizador é na região do vermelho, sendo assim, a contribuição na região de $418 \mathrm{~nm}$ será apenas da sonda DPBF.

Primeiramente medimos o decaimento da absorção do DPBF apenas em tampão fosfato (Figura 4.9) para verificar seu comportamento nas condições de medidas. Observamos uma leve degradação devido a exposição a luz.

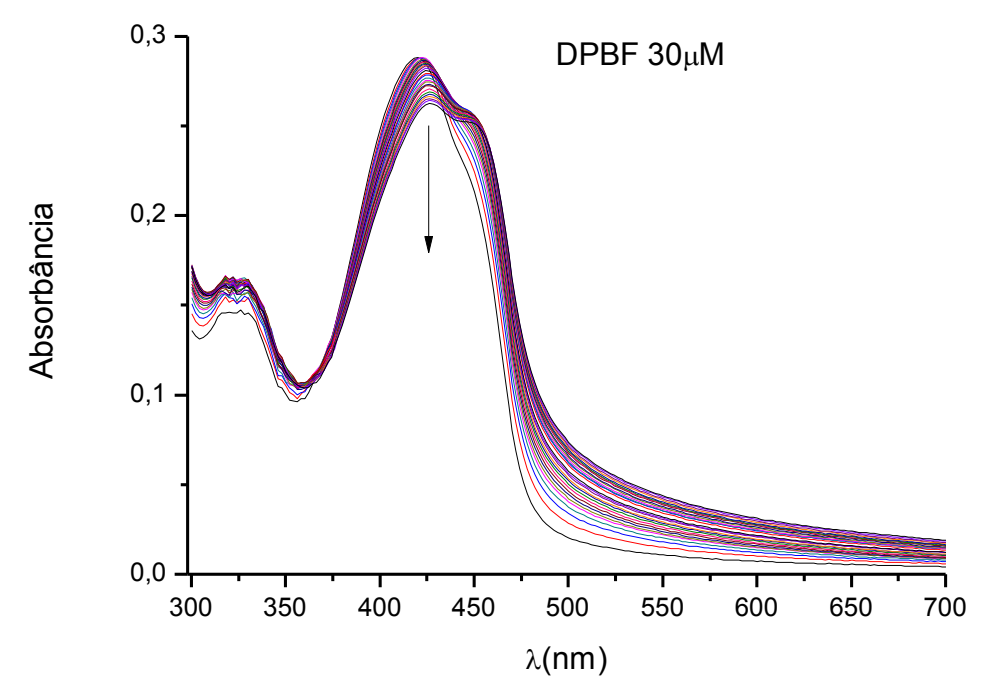

Figura 4.9 Decaimento de DPBF (30 $\mu \mathrm{M})$ apenas em solução de tampão fosfato 10 mM, pH 7,4. 
Depois a análise foi feita na presença de azul de metileno $2 \mu \mathrm{M}$ no mesmo tampão, para observarmos a contribuição do $\mathrm{MB}$, para a produção de ${ }^{1} \mathrm{O}_{2}$ durante a irradiação. Podemos observar, pelos espectros da Figura 4.10, que o decaimento da sonda DPBF é mais rápido que sem a adição do fotossensibilizador.

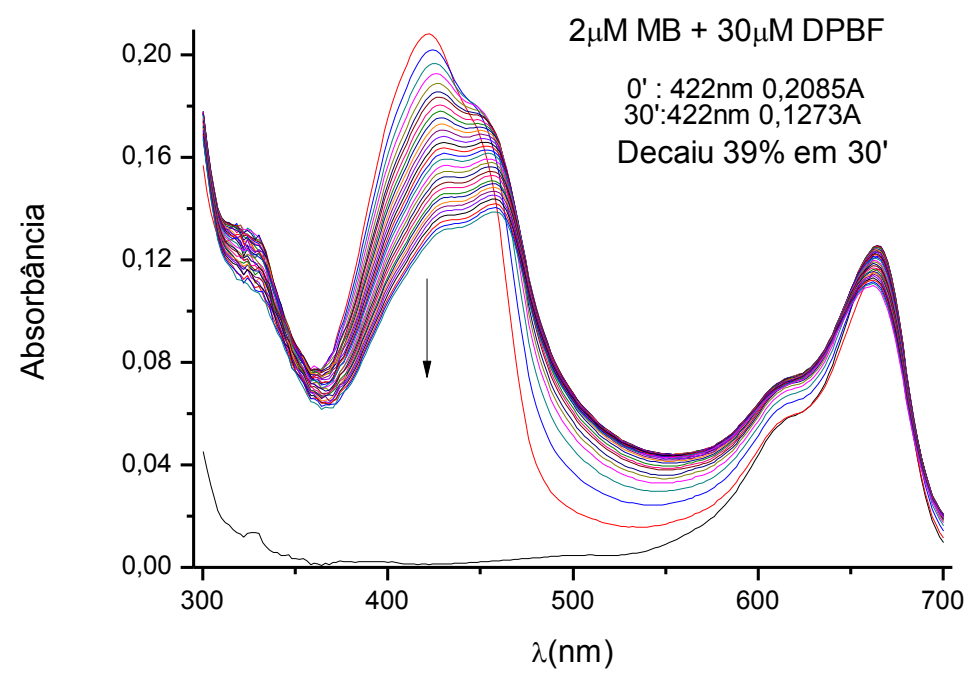

Figura 4.10 Decaimento de DPBF $30 \mu \mathrm{M}$ em solução tampão fosfato $10 \mathrm{mM}$, pH 7,4, e azul de metileno $2 \mu \mathrm{M}$.

Em seguida analisamos o comportamento do decaimento da sonda DPBF em azul de metileno $2 \mu \mathrm{M}$, na presença de micelas de PF-127 (Figura 4.11). O decaimento da sonda foi acelerado em relação aos anteriores. Nossa hipótese é de que a hidrofobicidade tanto do azul de metileno quanto da sonda DPBF implique em maior concentração de ambos nos compartimentos micelares de Pluronic F-127, aumentando a eficiência de degradação do DPBF pelo ${ }^{1} \mathrm{O}_{2}$ produzido pelas moléculas de MB adjacentes. 


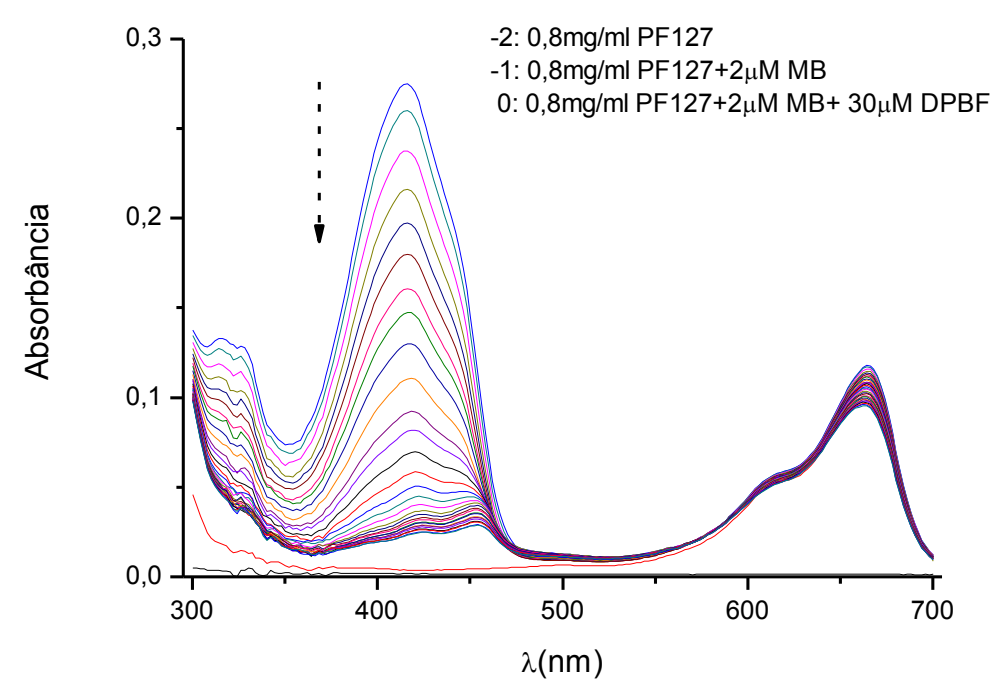

Figura 4.11 Decaimento de DPBF $30 \mu \mathrm{M}$ em solução com 0,8 mg/ml de Pluronic F-127, $2 \mu \mathrm{M}$ de azul de metileno em tampão fosfato $10 \mathrm{mM}$

A partir dos espectros das Figuras 4.9, 10 e 11, fizemos o gráfico da Figuras 4.12 e 13, que mostram a variação da absorbância no pico de absorção do DPBF, em $418 \mathrm{~nm}$, em função do tempo de irradiação das amostras, para os três casos analisados.

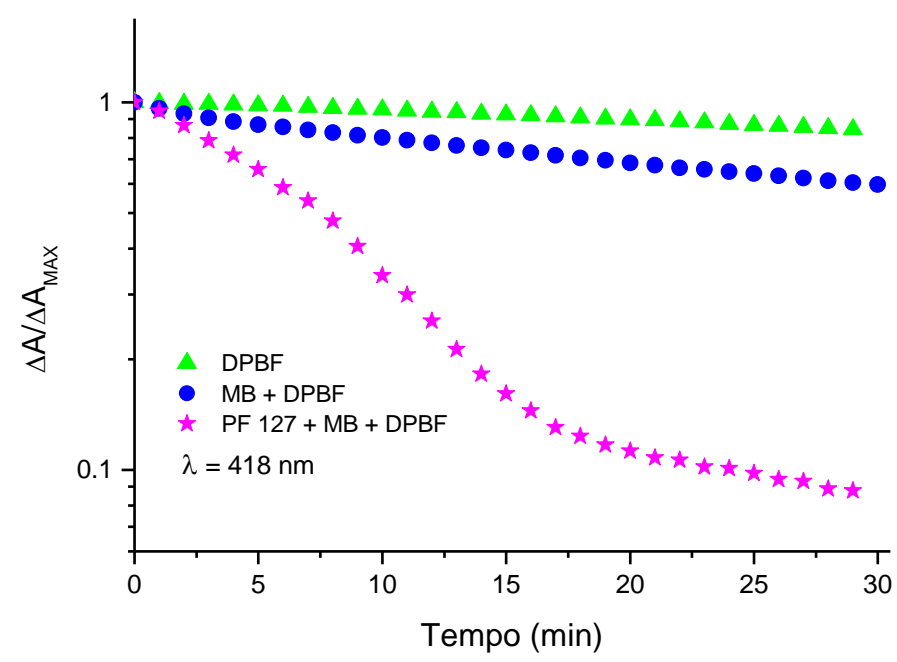

Figura 4.12. Decaimento da absorção de DPBF no comprimento de onda $418 \mathrm{~nm}$ em função do tempo de irradiação. 


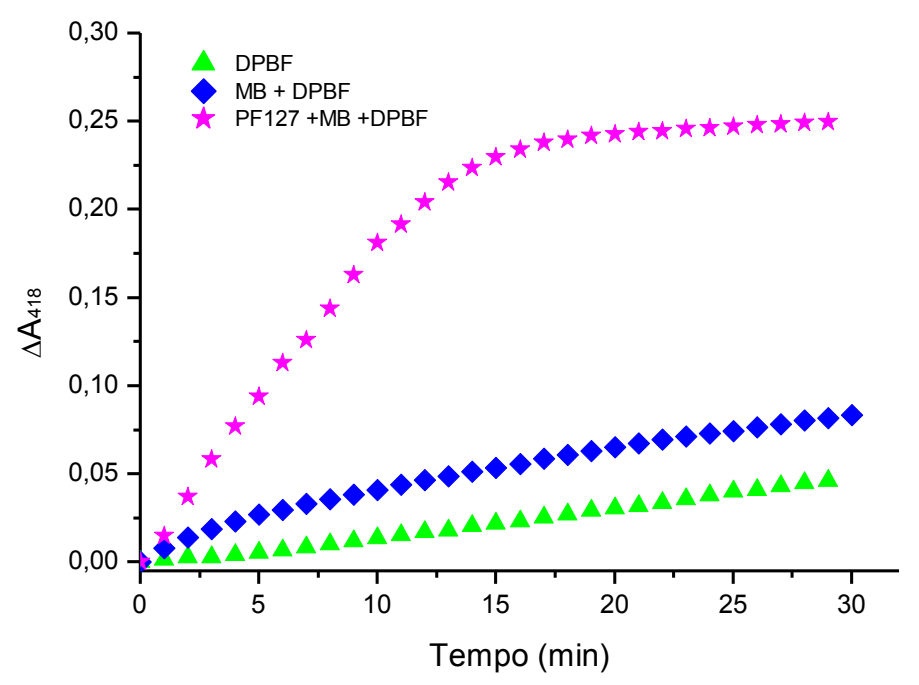

Figura 4.13. Variação da absorção de $\operatorname{DPBF}\left(\triangle \mathrm{A}=\mathrm{A}_{0}-\mathrm{A}\right)$ no comprimento de onda $418 \mathrm{~nm}$ em função do tempo de irradiação.

Observamos que o DPBF degrada apenas na presença da luz ambiente (LED irradiando em $650 \mathrm{~nm}$ ), mesmo em ausência de fotossensibilizador, ainda que muito lentamente. A degradação é acelerada com adição de azul de metileno e destacamos o decaimento abrupto quando utilizamos o polímero Pluronic F-127 (Figura 4.12). Observa-se que o PF-127 intensifica o decaimento, indicando, como sugerido acima, que o DPBF e o MB são encapsulados pelas micelas do copolímero, apresentando um efeito amplificado de fotodegradação por aumento da concentração local de ambos e consequente diminuição da distância entre a espécie reativa e a molécula sonda.

Também analisamos o decaimento na região de absorção do azul de metileno, relacionado com a fotodegradação do próprio fotossensibilizador e calculamos a taxa de decaimento (Figura 4.14). 


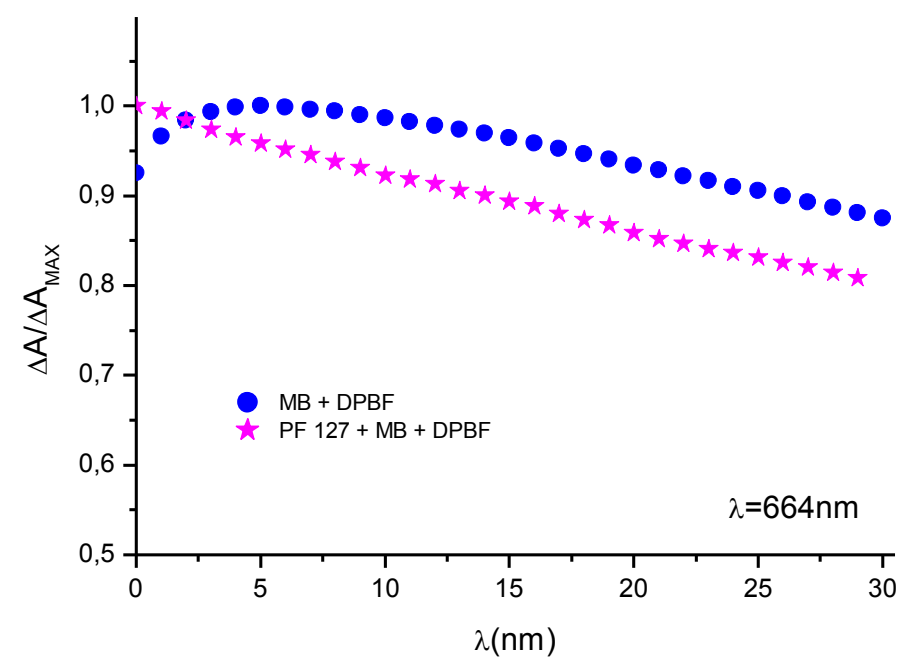

Figura 4.14. Decaimento da absorção no comprimento de onda $664 \mathrm{~nm}$ (referente ao pico de absorção do azul de metileno) em função do tempo.

Pelo gráfico da Figura 4.13 observamos que o decaimento no comprimento de onda $664 \mathrm{~nm}$, proveniente de uma degradação do azul de metileno é pequeno quando comparado à taxa de decaimento em 418 nm (Figura 4.12,) na região de absorção do DPBF.

Para continuar nosso estudo com as nanopartículas, utilizamos amostras em tampão fosfato $1 \mathrm{mM}$, cubeta de quartzo de $1 \mathrm{ml}$ com caminho óptico $1 \mathrm{~cm}$. Usamos ainda irradiação com o mesmo LED de $650 \mathrm{~nm}$ e tempos de irradiação de1 min entre as medidas.

Como referência, medimos o decaimento da sonda DPBF em tampão fosfato contendo $0,3 \mathrm{mg} / \mathrm{ml}$ de Pluronic F-127 e $2 \mu \mathrm{M}$ de MB para analisar o efeito do decaimento na ausência das nanopartículas (Figura 4.15 a).

Em seguida medimos as amostras com nanopartículas que passaram pelo mesmo procedimento que as amostras medidas com clorina e6. Dividimos o volume das nanopartículas vindas de uma mesma produção. Em parte, adicionamos o polímero Pluronic F-127 para estabilizar as nanopartículas, gerando as nanopartículas não aglomeradas (AuNP). Para aglomerar as nanopartículas adicionamos $\mathrm{NaCl}$ à outra parte para estimular a aglomeração. Logo após a uniformização o efeito de aglomeração é visível, na mudança de cor da solução e deslocamento da banda de absorção das nanopartículas. Adicionamos o PF-127 para estabilizá-las, impedindo a continuação do efeito de agregação. 

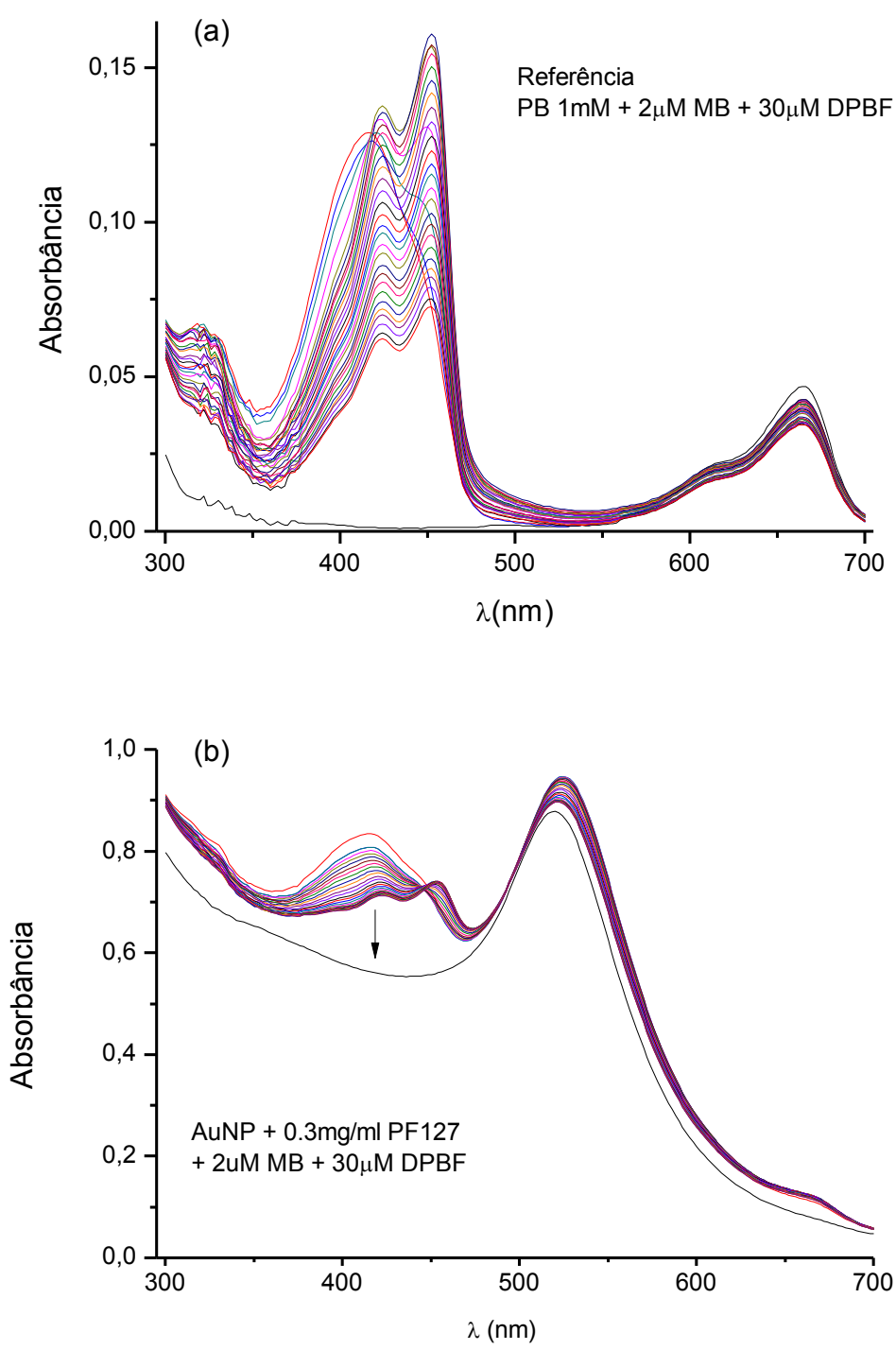

Figura 4.15. Decaimento do espectro de absorção de (a) DPBF em azul de metileno $2 \mu \mathrm{M}$ sob iluminação com LED de $650 \mathrm{~nm}\left(\mathrm{~A}_{664}=0,042\right)$ (Houve alguma reação que modificou o espectro de DPBF) (b) DPBF $30 \mu \mathrm{M}$ em AuNP + PF127 0,3mg/ml + MB $2 \mu \mathrm{M}\left(\mathrm{A}_{660}=0,02 \mathrm{MB}\right)$

Após uma noite estabilizadas com o polímero PF-127, acrescentamos a mesma concentração de azul de metileno às amostras. As medidas foram feitas no terceiro dia, uma noite da adição do azul de metileno.

Nossa primeira medida do decaimento do pico de absorção do DPBF foi com as nanopartículas não aglomeradas (AuNP) (Figura 4.15 b) em Pluronic F-127 e azul de metileno. Medimos inicialmente o espectro da amostra sem a sonda e em seguida o decaimento depois que a acrescentamos. Essas medidas foram realizadas em sequência. Observamos no gráfico (Figura 4.15 b) a linha preta sendo apenas a amostra sem a sonda e, após a adição da mesma, os espectros (coloridos) decaindo 
na região de absorção de DPBF, o que indica a produção do oxigênio singlete pelo fotossensibilizador.

Em seguida, seguindo o mesmo procedimento, fizemos análise similar utilizando as nanopartículas aglomeradas. Fizemos dois grupos, pois achamos que no primeiro a aglomeração apresentou deslocamento insuficiente da banda de ressonância plasmônica para a região do vermelho, efeito que pode ter sido causado pela rápida adição do polímero no momento de aglomeração por $\mathrm{NaCl}$, interrompendo a aglomeração antes da hora.
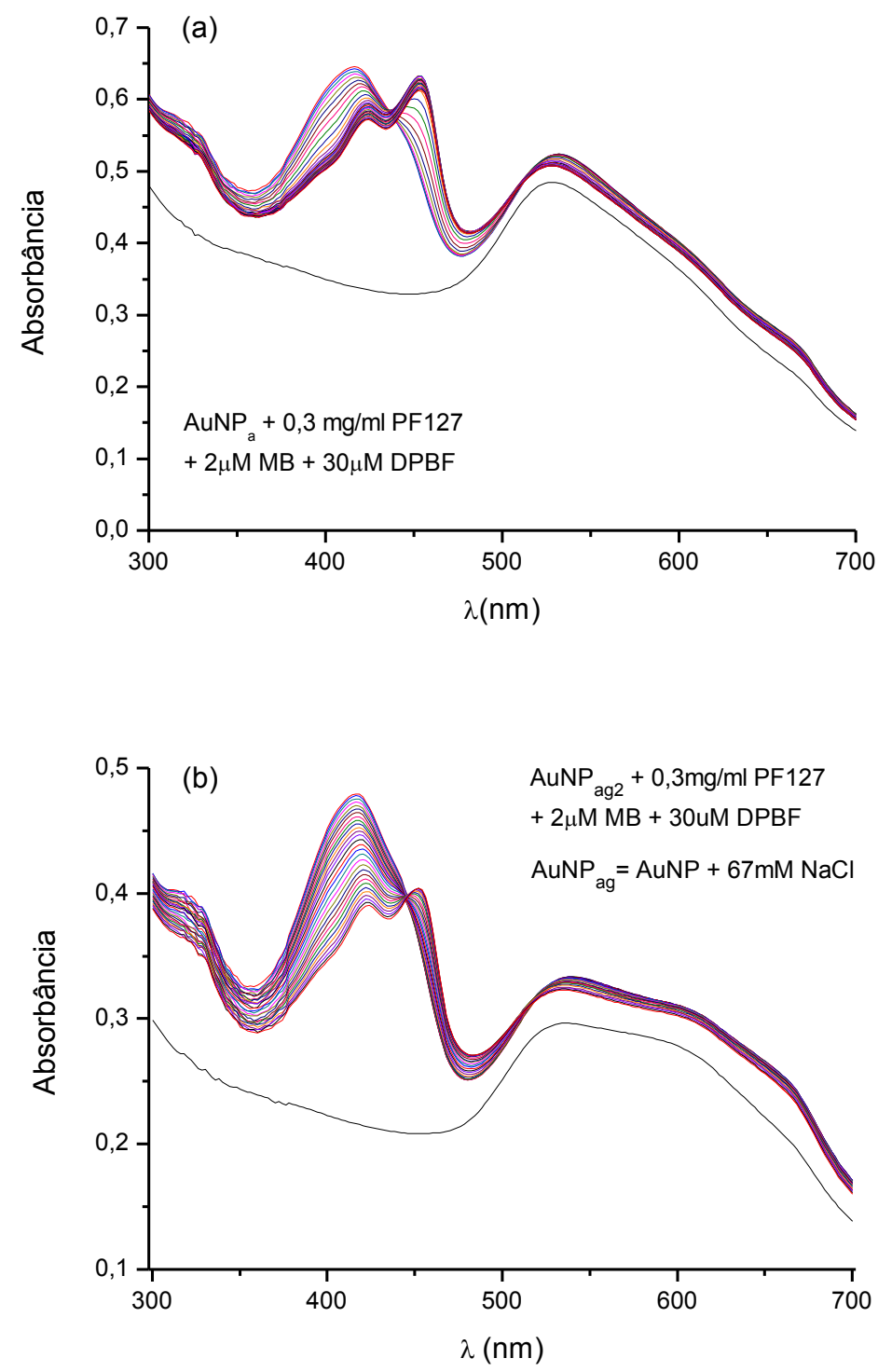

Figura 4.16. Decaimento do DPBF em AuNP $\mathrm{ag}_{2}+0,3 \mathrm{mg} / \mathrm{ml}+2 \mu \mathrm{M}$ de $\mathrm{MB}+30 \mu \mathrm{M}$ DPBF 
Nos espectros de absorção (Figura 4.16 a e b) a linha de base (contínua preta) é a nossa amostra sem a adição da sonda DPBF. Podemos observar a diferença da aglomeração devida ao tempo para uniformizar e adicionar PF-127 às nanopartículas após a adição de $\mathrm{NaCl}$. No caso da Figura 4.16 (a), o tempo foi menor e vemos pouca aglomeração devido ao pouco alargamento e deslocamento da banda plasmônica das nanopartículas. Já a Figura 4.16 (b) mostra um maior alargamento e deslocamento para a região do vermelho. As linhas contínuas e coloridas mostram o decaimento da sonda DPBF durante a irradiação devido à produção do oxigênio singlete pelo fotossensibilizante.

Com o intuito de analisar a taxa de decaimento da sonda DPBF em função do tempo, escolhemos os comprimentos de onda $418 \mathrm{~nm}$ referente ao pico de absorção da sonda DPBF.

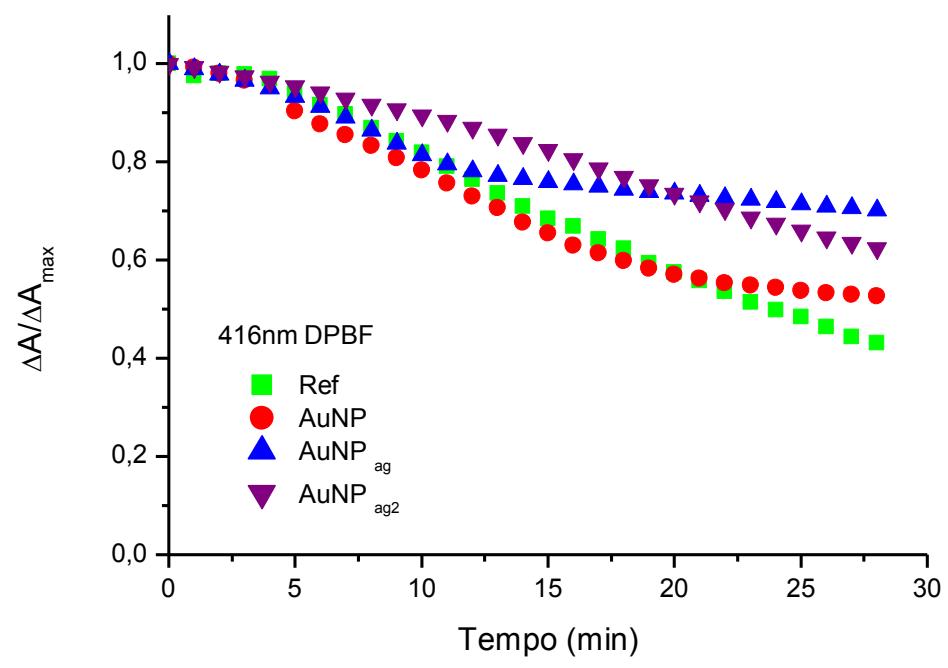

Figura 4.17. Decaimento da absorção do DPBF em função do tempo de iluminação, no comprimento de onda $416 \mathrm{~nm}$ para as quatro amostras medidas.

Na Figura 4.17, $\Delta \mathrm{A}=\left(\mathrm{A}-\mathrm{A}_{0}\right)$ e $\Delta \mathrm{A}_{\max }=\left(\mathrm{A}_{\max }-\mathrm{A}_{0}\right)$, sendo $\mathrm{A}$ a absorção no tempo específico, $\mathrm{A}_{0}$ a absorção inicial, antes de acrescentar DPBF, e $\mathrm{A}_{\max }$ a absorção máxima, logo após colocamos DPBF. Com base no gráfico (Figura 4.17), observamos que a taxa de decaimento não foi uniforme durante todo o experimento.

Para uma melhor análise, fizemos o gráfico (Figura 4.18) no qual normalizamos a variação do espectro da absorção do DPBF pela concentração de azul de metileno em cada amostra. As concentrações de MB foram obtidas pelos espectros de absorção (Figs. 4.15 e 4.16) e tomadas como sendo proporcionais à 
diferença entre as absorbâncias no pico de MB, em 664, e em 700 nm ( $\left.\mathrm{A}_{664}-\mathrm{A}_{700}\right)$. Podemos observar que a produção de oxigênio pelas amostras com nanopartículas é maior que a da amostra de referência. Também é possível notar que as nanopartículas aglomeradas $\left(\mathrm{AuNP}_{\mathrm{a}}\right)$ mostraram maior eficiência que as não aglomeradas (AuNP), provavelmente pelo deslocamento batocrômico da banda plasmônica, que apresentou maior sobreposição com a banda de absorção do azul de metileno.

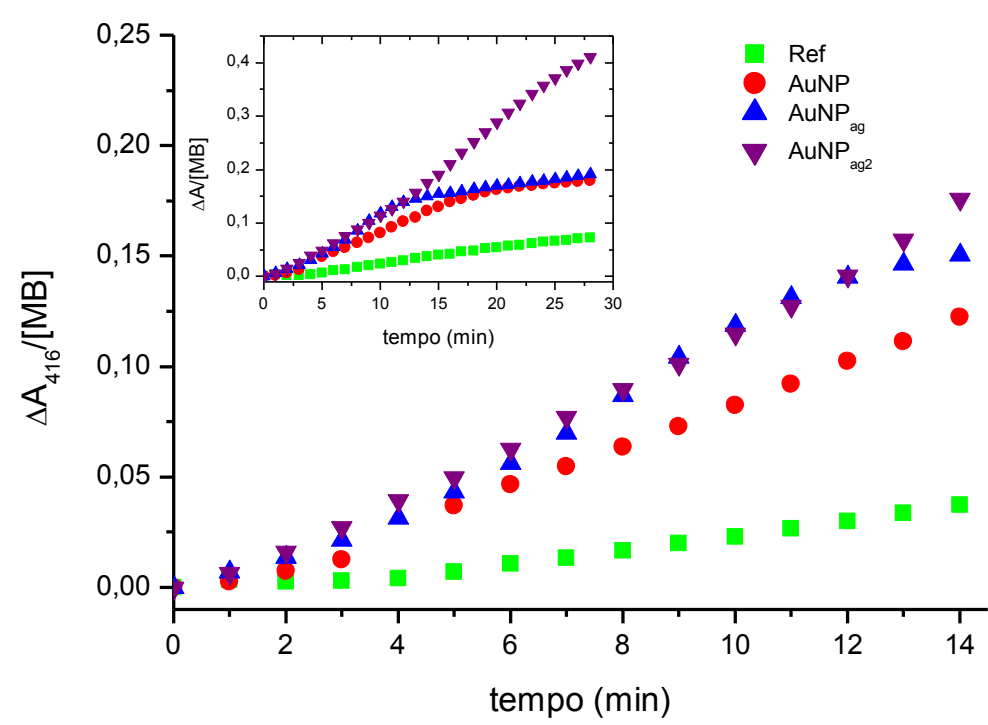

Figura 4.18. Variação da absorção de $\operatorname{DPBF}\left(\Delta \mathrm{A}=\mathrm{A}_{0}-\mathrm{A}\right)$ no comprimento de onda $416 \mathrm{~nm}$ em função do tempo de irradiação.

Para medidas com tempos após 14 min, o mesmo gráfico (Figura 4.18) apresenta uma mudança de comportamento em uma das amostras das nanopartículas aglomeradas. Inicialmente mostra uma taxa de consumo similar à de $\mathrm{AuNP}_{\text {ag2}}$, mas após um tempo de medida seu espectro se torna similar ao das AuNP indicando que o consumo ou a produção de oxigênio singlete diminuiu. O que poderia ser explicado por algum defeito na iluminação do LED já que a mudança na taxa de variação foi abrupta.

Essas medidas foram realizadas apenas uma vez e, portanto, necessitamos realizar experimentos estatisticamente confiáveis, em triplicata, controlando mais as condições experimentais, para verificar alguma diferença real. No entanto, a eficiência na produção de oxigênio singlete pelos dois fotossensibilizantes, clorina 
e6 e azul de metileno, associados a nanopartículas de ouro seguiu a mesma tendência: $\mathrm{AuNP}_{\mathrm{ag}}>\mathrm{AuNP}>$ controle. 


\section{5}

\section{Conclusão}

As nanopartículas de ouro feitas por ablação a laser em água, são estáveis por extensos períodos de tempo, mas ficam instáveis e aglomeram em condições fisiológicas, em alta força iônica. Verificamos que o copolímero Pluronic F-127 estabiliza essas nanopartículas formando uma camada com dupla funcionalidade hidrofóbica/hidrofílica, capaz de reter algumas substâncias de interesse biológico e farmacológico, incluindo fotossensibilizadores.

Nanopartículas com bandas de ressonância plasmônica em 520 nm (não aglomeradas) e deslocadas para o vermelho $\sim 600 \mathrm{~nm}$ (aglomeradas) foram estabilizadas com PF127 e preparadas com dois tipos de fotossensibilizadores bastante utilizados, clorina e6 e azul de metileno. Os dois fotossensibilizadores apresentaram localização preferencial na camada polimérica superficial das nanopartículas, indicando que estas têm potencial para utilização em distribuição controlada dos fotossensibilizadores. Visto que não são tóxicas e mantêm ou amplificam a taxa de produção de espécies citotóxicas como oxigênio singlete, são promissoras na composição de materiais para uso em terapia fotodinâmica (PDT).

Para as medidas utilizando o fotossensibilizador clorina e6, as amostras com nanopartículas apresentaram maior taxa de decaimento da sonda DPBF, tendo apresentado maior eficiência as nanopartículas com bandas plasmônicas deslocadas para o vermelho (aglomeradas).

Para as medidas utilizando o fotossensibilizador azul de metileno, as amostras em PF-127 sem nanopartículas aparentaram ser mais eficientes, mas acreditamos que possa ter sido o efeito hidrofóbico nas micelas formadas pelo polímero Pluronic F-127, concentrando a sonda DPBF e o fotossensibilizador azul de metileno nos compartimentos micelares. Por consequência, o DPBF estaria mais próximo do local de produção do oxigênio singlete, e apresentaria um decaimento mais eficiente, o que não necessariamente indica maior taxa de produção do radical pelo fotossensibilizador. As amostras com nanopartículas de ouro, tanto aglomeradas $\left(\mathrm{AuNP} \mathrm{ag}_{\mathrm{g}}\right)$ como não aglomeradas (AuNP), não apresentaram esse efeito de entrada 
do DPBF, talvez porque as moléculas do polímero já estariam formando uma camada ao redor das nanopartículas e não estariam livres para formar as micelas.

Para o fotossensibilizante azul de metileno as medidas apresentaram um maior consumo de oxigênio singlete para amostras com nanopartículas que para amostras sem nanopartículas. Além disso, nanopartículas aglomeradas apresentaram maior eficiência no processo, visto que o consumo de DPBF foi acelerado na presença delas.

Para ambos fotossensibilizadores, não apenas vimos uma melhora na eficiência de produção de ${ }^{1} \mathrm{O}_{2}$ ao utilizar essas nanopartículas, como observamos as nanopartículas aglomeradas como mais eficientes.

Com base nesses argumentos, sugerimos que nossos nanocompósitos de nanopartículas de ouro recobertas e estabilizadas com polímero Pluronic F-127, associados com fotossensibilizadores, tanto o azul de metileno quanto a clorina e6, são fortes candidatos a tratamentos utilizando a terapia fotodinâmica como base. 
6

\section{Referências bibliográficas}

Abdullin, T. I.; Bondar, O. V.; Shtyrlin, Y. G.; Kahraman, M.; Culha, M. Pluronic

Block Copolymer-Mediated Interactions of Organic Compounds with Noble Metal Nanoparticles for SERS Analysis. Langmuir. 26 (7)5153-5159.2009.

Amendola, V.; Pilot, R.; Frasconi, M.; Maragò, O. M.; Iatì, M. A. Surface Plasmon Resonance in Gold Nanoparticles: A Review. Journal of Physics: Condensed Matter. 2017.

Amendola V.; Meneghetti, M. What Controls the Composition and the Structure of Nanomaterials Generated by Laser Ablation in Liquid Solution? Phys. Chem. Chem. Phys. 15. 3027. 2013.

Bonnet R. Photosensitizers of the Porphyrin and Phthalocyanine Series for Photodynamic Therapy. Chem. Soc. Rev. 24, 19-35, 1995.

Borissevitch, I. E.; Ferreia, L. P. A Luz na Medicina Moderna. Fotoquimioterapia. 2016.

Carloni, P.; Damiani, E.; Greci, L.; Stipa, P.; Tanfani, F.; Tartaglini, E.; Wozniak, M. On the Use of 1,3-Dipheylisobenzofuran (DPBF). Reactions with Carbon and Oxygen Centered Radicals in Model and Natural Systems. Res Chem Intermed (1993) 19: 395.

Calvete, M.; Gomes, A.; Moura, N. Clorinas em Terapia Fotodinâmica - Sínteses e Aplicações. Revista Virtual de Química, Aveiro - Portugal, v. 1, n.2, p. 92-103, 08 abr. 2009.

Cunderlikova, B.; Gangeskar, L.; Moan, J.. Acid-Base Properties of Chlorin e6: Relation to Cellular Uptake. J. PhotoChem.Photobiol. B: Biol. 53. 81-90. 1999. 
Del Rosso, T.; Louro, S. R. W.; Deepak, F. L.; Romani, E. C.; Zaman, Q.; Tahir; Pandoli, O.; Cremona, M.; Freire Júnior, De Buele, P.; F. L.; De St. Pierre, T.; Aucelio, R. Q.; Mariotto, G.; Gemini-Piperni, S.; Ribeiro, A. R.; Landi, S. M.; Magalhães, A. Biocompatible Au@Carbynoid/Pluronic-F127 Nanocomposites Synthesized by Pulsed Ablation Assisted $\mathrm{CO}_{2}$ Recycling. Applied Surface Science. 441. 347-355. 2018.

Dougther, T.H.; Boyle, D.G.; Weishaupt, K; Gomer, C.; Borcicky, D.; Kaufman, J.H.; Grindey, G.; In Research in Photobiology. Plenum Publish Corporate, NY. 435-466. 1977.

Dougherty, T. J; Kaufman, J. E. ; Goldfarb, A.; Weishaupt, K. R.; Boyle, D.; Mittleman, A.. Photoradiation Therapy for the Treatment of Malignant Tumors. Cancer Research. 38 (8): 2628-35. 1978.

Galo, A. L.; Colombro, M F. Espectrofotometria de Longo Caminho Óptico em Espectrofotômetro de Duplo-Feixe Convencional: uma Alternativa Simples para Investigações de Amostras com Densidade Óptica Muito Baixa. Quim. Nova. 32 (2). 2009.

Huang, X. \& El-Sayed, M. A.. Gold Nanoparticles: Optical Properties and Implementations in Cancer Diagnosis and Photothermal Therapy. Journal of Advanced Research, 1, 13-28.2010.

Kavarnos, G. J. \& Turro, N. J. Photosesnsitization by Reversible Electron Transfer: Theories, Experimental Evidence, and Examples. ChemRev.86 (2). 401-449. 1986.

Machado A. Terapia Fotodinâmica: Princípios, Potencial de Aplicação e Perspectivas. Química Nova. 23, 237-243, 2000.

Mellish, Kirste, R Cox, D Vernon, J Griffiths, e S Brown. "In Vitro Photodynamic Activity of a Series of Methylene Blue Analoques." Photochemistry and Photobiology American Society for Photobiology. 75 ed.2002. 
Mie G. A Contribution to the Optics of Turbid Media, Especially Colloidal Metallic Suspensions. Ann Phys .25:377-445. 1908.

Nelson, D. L.; Cox, M. L. . Princípios de Bioquímica de Lehninger. Artmed, 2014.

Oliveira, K. T.; de Souza, J. M.; Gobo, N. R.S.; de Assis, F.F.; Brocksom, T. J. Conceitos Fundamentais e Aplicações de Fotossensibilizadores do Tipo Porfirinas, Clorinas e Fitalocianinas em Terapias Fotônicas. Rev. Virtual Química, 7(1). 310-335. 2015.

Radaev, A. Historical Aspects of Photodynamic Therapy Development, The "Magic Ray". Moscow center of Laser Medicine. http://www.magicray.ru/PDT_Photodynamic_therapy/Oncology_lectures/Historic al_aspects_of_PDT_development.html.

Rahme, K., Oberdisse, J., Schweins, R.; Gaillard, C. Marty, J. D.;Mingotaud, C.; Gauffre, F. Pluronic-Stabilized Gold Nanoparticles: Investigation of the Sructure of Polymer-Particle Hybrid. Chem.PhysChem.9.2230-2236.2008.

Ronsein, G. E.; Miyamoto, S.; Bechara, E.; Di Mascio, P.; Martinez, G. R. Oxidação de Proteínas por Oxigênio Singlete: Mecanismos de Dano, Estratégias para Deteç̧ão e Implicações Biológicas. Quim Nova, 29 (3). 2006.

Scwingel, A.R.; Barcessat, A. R. P.; Núñez, S. C., Ribeiro, M. S. Antimicrobial Photodynamical Therapy in the Treatment of Oral Candidiasis in HIVinfected Patients. Photomed. Laser Surg. 30. 429- 432. 2012.

Simon, T.; Potara, M.; Gabudean, A. M.; Licarete, E.; Banciu, M., Astilean, S. Designing Theragnostic Agents Based on Pluronic Stabilized Gold Nanoaggregates Loaded with Methylene Blue for Multimodal Cell Imaging and Enhanced Photodynamic Therapy. ACS Appl. Mater. Interfaces. 7. 16191201.2015. 
Solovieva A. B.; Melik-Nubarov N. S.; Zhiyentayev T. M.; Tolstih P. I., Kuleshov,I. I.; Aksenova N. A.; Litmanovich E. A.; Glagolev N. N., Timofeeva V. A.; Ivanov A. V.. Development of Novel Formulations for Photodynamic Therapy on the Basis of Amphiphilic Polymers and Porphyrin Photosensitizers. Pluronic Influence on Photocatalytic Activity of Porphyrins. Laser Physics. 19, 817-824, 2009.

Song, D.; Lindoso, J. J. L.; Oyafuso, L. K. ; Kanashiro, E. H. Y. Cardoso, J. L.; Uchoa, A. F.; Tardivo, J.; Baptista, M.S. Photodyamic Therapy Using Methylene Blue to Treat Cutaneous Leishmaniasis. Photomed. Laser Surg.29. 711-715. 2011.

de Souza, R. M.; Siani, P.; Schmidt, T. F.; Itri R. Dias, L. G. Methylene Blue Location in (Hydroperoxized) Cardiolipin Monolayer: Implication in Membrane Photodegradation. J. Phys. Chem. B. 121. 8512-8522. 2017.

Tardivo, J. P. ; Del Giglio, A.; Paschoal, L. H.; Baptista, M. S.. Photodynamic Therapy using Methylene Blue to Treat Cutaneous Leishmaniasis. Photomed. Laser Surg. 29.711-715.2011.

Vivero-Estoco, J. L.; Huang, Y. T.. Inorganic-Organic Hybrid Nanomaterials for Therapeutic and Diagnostic Imaging Applications. Int. J. Mol. Sci. 12. 38883927. 2011.

Wagner, M.; Suarez, E. R.; Theodoro, T. R.; Machado Filho, C. D. A. S.; Gama, M. F. M.; Tardivo, J. P.; Pachoal, F. M.; Pinhal, F. M. A. S. Methylene Blue Photodynamic in Malignant Melanoma Decreases Expression of Proliferating Cell Nuclear Antigen and Heparanases. Clin. Exp. Dermatol. 37.527-533. 2012.

Wainwright, M. Methylene Blue Derivative - Suitable Photoantimicrobials for Blood Product Disinfection? Int J Antimicrob Agents.16.381-394. 2000. 
Zhang, X. F.; Li, X..The Photostability and Fluorescence Properties of Diphenylisobenzofuran . Journal of Luminescence 131. 2263-2266. 2011.

Zhou, J.; Ralston, R.; Sedev, D. A.; Beattie, J.. Functionalized Gold Nanoparticles: Synthesis, Structure and Colloid Stability. Colloid Interface Sci. 331. 251. 2009.

Zou, Y; Gong, Y.; Lin, B., Mellott. Photodegradation of Methylene Blue in the Visible Spectrum: Na Efficient $\mathbf{W}^{6+}$ Ion Doped Anatase Titania Photocatalyst via a Solvothermal Method. 126.63-69.2016 
7

\section{Apêndice}

A fim de minimizar os erros durante as medidas, montamos um circuito simples para maior controle da intensidade da luz do LED. O esquema (Figura7.1) foi idealizado pelo antigo técnico do Departamento de Física da PUC-Rio, João Manoel. Esse circuito trabalha mantendo fixa a corrente e controla a intensidade por meio da modulação da largura do pulso.

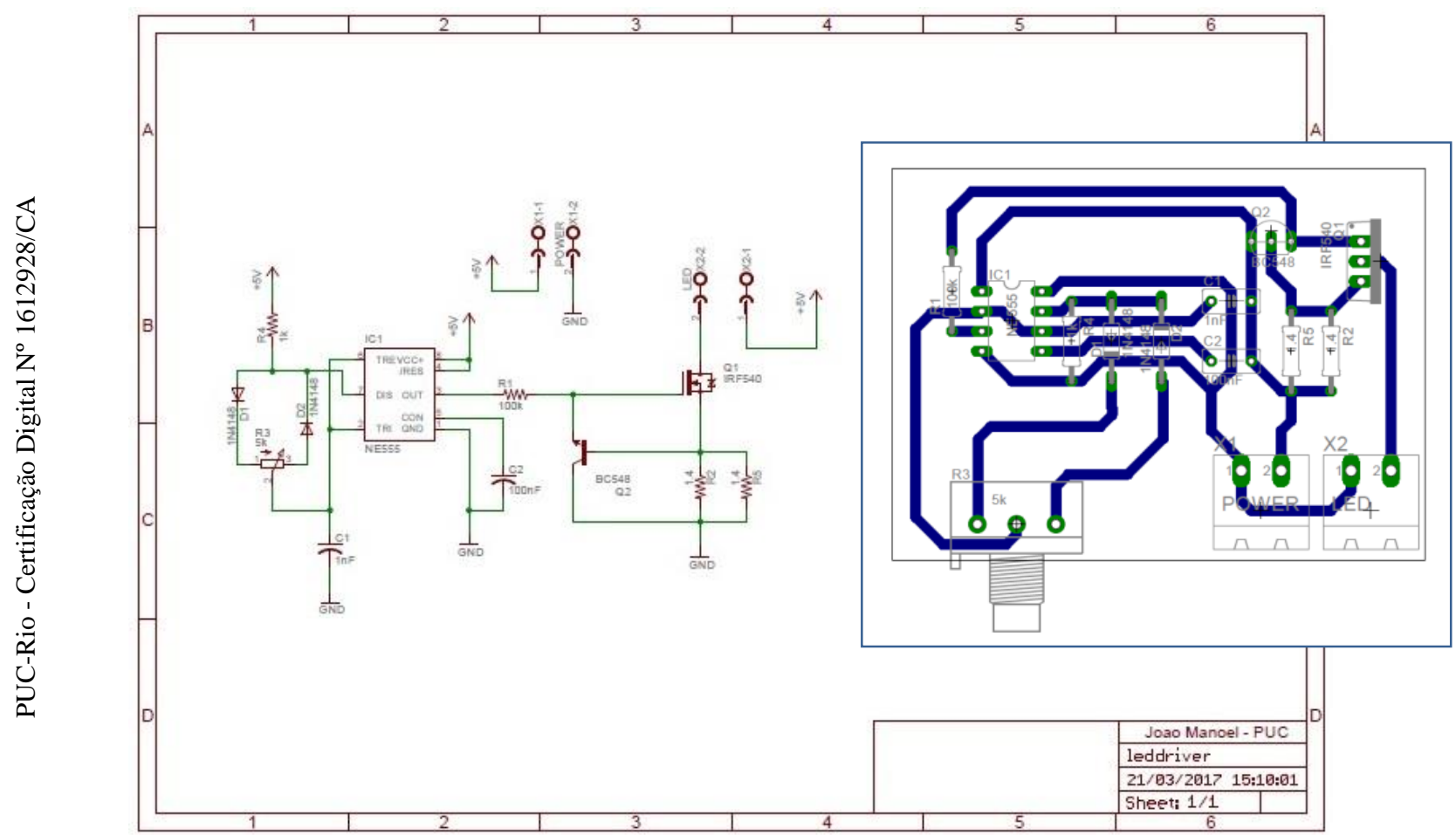

Figura 7.1 a) Esquema elétrico do circuito e b) o desenho para impressão do circuito controlador da intensidade do LED

A Figuras 7.1 a apresenta o esquema elétrico para montagem do circuito com as peças e seus valores necessários. A Figura $7.1 \mathrm{~b}$ mostra o desenho esquemático com o posicionamento e o caminho (em azul) para ligações das peças. Esse desenho foi utilizado para fabricação do circuito impresso em máquina $\mathrm{CNC}$. 
Após o circuito ser impresso, trabalhamos na montagem soldando as peças e colocamos em um suporte de acrílico. O LED foi fixado em um suporte de alumínio para ajudar na dissipação de calor gerado.

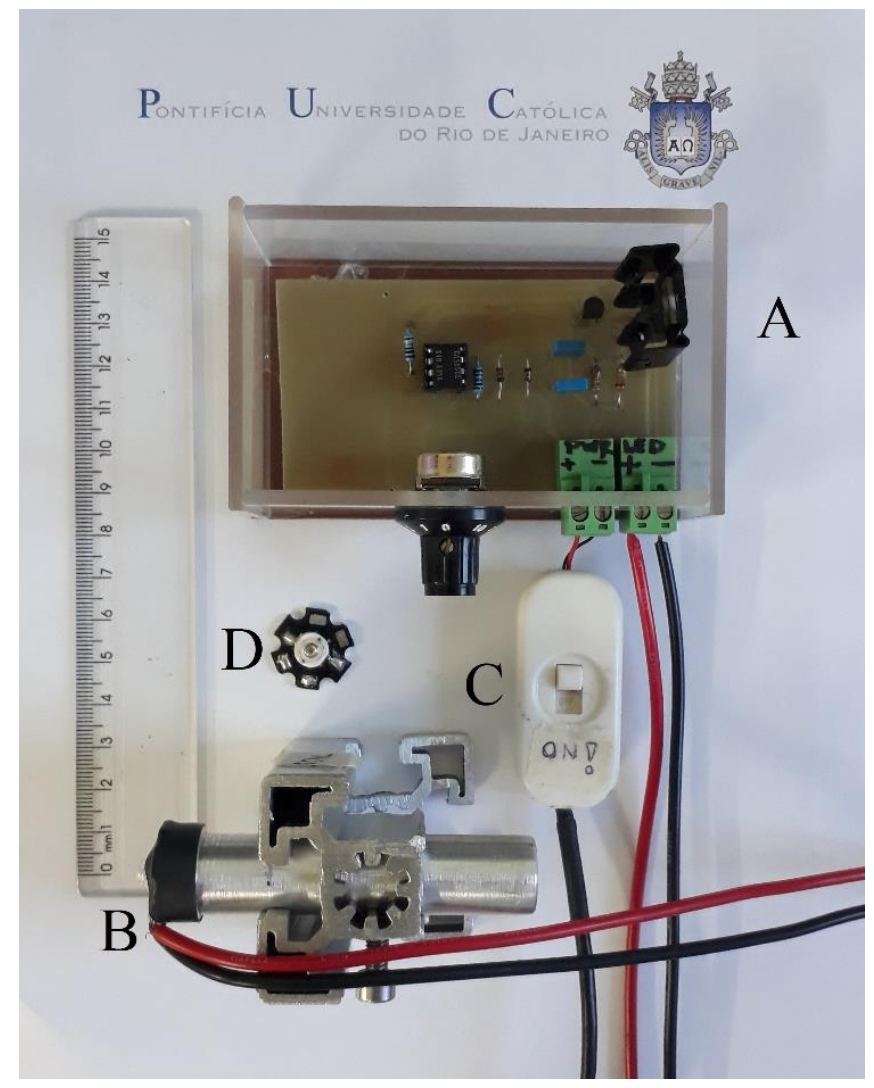

Figura 7.2 Foto do circuito utilizado, aberto com o LED

A Figura 7.2 apresenta a foto do circuito montado (A), o LED fixado no suporte de alumínio (B), com o interruptor ligando o LED ao circuito (adaptado para ligar e desligar mantendo fixa a intensidade da luz quando religado) e o LED solto (D) visto de frente. 